\title{
Palaeogeographic reconstruction of a fluvio-marine transitional system in Narmada rift basin, India - Implications on Late Cretaceous global sea-level rise
}

\author{
Biplab Bhattacharya ${ }^{1 *}$, Suparna $\mathrm{Jha}^{2}$ and Prantik Mondal ${ }^{1}$
}

\begin{abstract}
Rising sea-levels in tectonically active epicontinental basins often lead to varied depositional settings and palaeogeography, mostly influenced by the net accommodation resulting from mutual interference of the extent and nature of landward encroachment by the sea and the net sedimentation. The Cenomanian Nimar Sandstone Formation, Bagh Group, Narmada rift basin, uniquely portrays the effect of sea-level rise within an intra-cratonic setting and attributes to the corresponding palaeogeographic changes in west-central India. An integrated sedimentological-sequence-stratigraphic study of the broadly fining-upward Nimar Sandstone Formation (thickness $\sim 20-30 \mathrm{~m}$ ) depicts the actual nature of changeover from a fluvial to a marine-dominated transitional depositional setting. Detailed sedimentological study reveals total seventeen facies, grouped in five facies associations, viz., the channel-fill facies association (FA-1), the overbank facies association (FA-2), the fluvial-dominated fluvio-tidal facies association (FA-3), the tide-dominated fluvio-tidal facies association (FA-4), and the shoreface facies association (FA5). Overall facies architecture indicates a west-to-eastward marine encroachment, resulting in stacking of three distinct palaeo-depositional conditions: (i) an initial fluvial system with channel and overbank, changing into a tideinfluenced fluvial bay-head delta in the inner estuary, followed by (ii) marine encroachment leading to a tidedominated central estuary with inter- to sub-tidal settings, and finally, (iii) with further intense marine encroachments, a wave-reworked open shore condition in the outer estuary zone. The overall fining-up succession with a systematic change from fluvial to marine-dominated depositional systems points to a landward shift of the shoreline, signifying a major transgressive event correlated to the Cenomanian global sea-level rise. Characteristic stratal stacking patterns point to four coarsening- and fining-up hemicycles, embedded within the major transgressive succession. These high-frequency cycles attest to the varied interplay of sedimentation, tectonics and sea-level changes, and the resultant net accommodations. A palaeogeographic model is proposed based on the high-frequency transgressive-regressive hemicycles, which envisages the evolution of the depositional environments in relation to the Cenomanian eustatic rise in the intra-cratonic riftogenic fluvio-marine transitional basinal setup.
\end{abstract}

Keywords: Late Cretaceous, Fluvial-estuary transition, Nimar Sandstone Formation, Bagh Group, Narmada rift basin, Transgressive-regressive cycles, Global sea-level

\footnotetext{
*Correspondence: biplab.bhattacharya@es.iitr.ac.in; bb.geol.dgc@gmail.com

'Department of Earth Sciences, Indian Institute of Technology, Roorkee

247667, India

Full list of author information is available at the end of the article
}

\section{Springer Open}

(-) The Author(s). 2020 Open Access This article is licensed under a Creative Commons Attribution 4.0 International License, which permits use, sharing, adaptation, distribution and reproduction in any medium or format, as long as you give appropriate credit to the original author(s) and the source, provide a link to the Creative Commons licence, and indicate if changes were made. The images or other third party material in this article are included in the article's Creative Commons licence, unless indicated otherwise in a credit line to the material. If material is not included in the article's Creative Commons licence and your intended use is not permitted by statutory regulation or exceeds the permitted use, you will need to obtain permission directly from the copyright holder. To view a copy of this licence, visit http://creativecommons.org/licenses/by/4.0/. 


\section{Introduction}

The Late Cretaceous time interval is known for intense tectonic activities and significant changes in climatic conditions (Miller et al. 2005; Sames et al. 2016) accompanied by prolonged sea-level rises, leading to worldwide inundations of landmasses (Hancock and Kauffman 1979; Förster et al. 1983; Hilbrecht et al. 1986; Haq et al. 1987; Hallam 1992; Röper and Rothgaenger 1995; Miller et al. 2005; Haq 2014). Several parts of different continents were affected by transgressions during the Late Cretaceous time, including parts of Arctic Canada, Russia, western Europe, eastern Australia, parts of Africa, South America, India, Madagascar, and Borneo. Most of the subcontinents of the supercontinent Gondwanaland were fully or partially submerged at different time intervals during the Late Cretaceous, which led to the formation of shallow epicontinental seas in certain areas. Evidence of Cretaceous sea-level rise in the Indian subcontinent is recorded within thick sedimentary successions of the Cauvery Basin (Nagendra et al. 2011, 2013), Shillong Basin (Singh and Mishra 2000), Kutch Basin (Desai 2013), Bengal-Assam Basin, parts of the Himalayan fold belt, and the Narmada rift basin in west-central India (Acharya and Lahiri 1991; Banerjee et al. 2020).

Such global eustatic changes generally manifest $1^{\text {st }}$ $2^{\text {nd }}$ order sea-level cycles affecting most of the continents, which allow for their successful correlations. However, associated higher-frequency cycles $\left(3^{\text {rd }}\right.$ order, $4^{\text {th }}$ order and beyond), included in the $2^{\text {nd }}$ order cycles, mostly depend on changes in relative sea-level and net accommodation caused by basin-scale tectonism, sedimentations and/or climatic/orbital forcings (Vail et al. 1991; Gale et al. 2002; Haq 2014; Bhattacharya and Bhattacharya 2015). The Cenomanian Stage (98.9-93.5 $\mathrm{Ma}$ ) provides a suitable window to study such changes, as high-resolution global correlations (100-400 kyr) in terms of sea-level changes and orbital cycles from marine successions revealed five major/minor eustatic events (KCe-1 to $\mathrm{KCe}-5$ of Haq 2014). However, doubt persists regarding actual nature and effect of transgressions in shallow marine and continent-margin transitional depositional areas, and the role of climatic forcings, tectonism, and sedimentation in controlling palaeogeography and shaping resultant stratal stacking patterns (Bhattacharya et al. 2018). High-resolution sequence-stratigraphic study backed by detailed sedimentary facies analysis is useful to understand the appropriate transitional relationship between fluvial and marine processes in terms of major transgressive-regressive cycles in response to tectonoeustatic changes in such basins (Bhattacharya et al. 2018; Jaiswal et al. 2018).

History of sea-level fluctuations during the Cenomanian time in the southern part of the Indian subcontinent
(Cauvery Basin) was documented by Sundaram et al. (2001), Skelton (2003), and Gale et al. (2002). However, the effects may vary significantly in fluvio-marine interactive systems depending on the prevalent tectonosedimentary equilibrium. Though attempts to understand the nature of the transition between fluvial and marine depositional systems are plenty in the literature (Dalrymple et al. 1992; Greb and Martino 2005; Dalrymple and Choi 2007; van den Berg et al. 2007; Bhattacharya et al. 2012; Bhattacharya and Banerjee 2015; Bhattacharya and Bhattacharya 2015; Bhattacharya et al. 2018; Richards and Bhattacharya 2018; Gugliotta et al. 2019; and references therein), gaps persist in the actual perception of basinscale facies architecture and stratal stacking pattern related to characteristic tectono-sedimentary attributes in shallow epicontinental basins.

The Nimar Sandstone (Cenomanian) Formation, the lowermost litho-unit within the Bagh Group (Late Cretaceous), bears signatures of the contemporary global sea-level rise in west-central India (Jha et al. 2017). Signatures of the Late Cretaceous marine transgression in the Bagh Group are evident and agreed well in terms of different proxies such as sedimentary attributes, palaeontological data, ichnological data, micropalaeontological data and palaeobotanical data (Murty et al. 1963; Chiplonkar and Ghare 1975; Raiverman 1975; Badve and Ghare 1980; Singh and Srivastava 1981; Jafar 1982; Bose and Das 1986; Ganguly and Bardhan 1993; Sanganwar and Kundal 1997; Khosla et al. 2003; Smith 2010; Jaitly and Ajane 2013; Bhattacharya and Jha 2014; Jha et al. 2017; Bansal et al. 2019; and many others). But, a comprehensive sequence stratigraphic model enumerating the actual nature of coastal onlap and the fluvial-marine interaction has not been attempted and is long overdue. The objective of the present paper is to document the palaeogeographic changes under the fluvio-marine interactive depositional system in the light of high-frequency transgressive-regressive $(\mathrm{T}-\mathrm{R})$ cycles. The proposed model will help to understand the effects of higherfrequency sea-level fluctuations in fluvio-marine transitional systems within a global eustatic rise condition.

\section{Geological setting}

The deposition of the Bagh Group (Late Cretaceous) was started within the Narmada rift basin during the Cenomanian time, directly overlying the Proterozoic Bijawar Group. The Bagh Group is constituted of three litho-units (formations), namely, the lowermost Cenomanian Nimar Sandstone Formation, followed by the Turonian Nodular Limestone Formation, and Coniacian Coralline Limestone Formation at the top (Table 1). In the Narmada rift basin, the Bagh Group is overlain by the Lameta Formation and the Deccan Traps, both of Late Cretaceous age. The presence of various sedimentary facies, ichnofabrics, and 
Table 1 Generalized lithostratigraphy of the study area (modified after Singh and Srivastava 1981; Jaitly and Ajane 2013)

\begin{tabular}{|c|c|c|c|c|}
\hline Series & Stage & Group & Formation & Member \\
\hline \multirow{6}{*}{$\begin{array}{l}\text { Upper } \\
\text { Cretaceous }\end{array}$} & \multirow{2}{*}{ Maastrichtian } & \multicolumn{3}{|l|}{ Deccan Traps } \\
\hline & & & \multicolumn{2}{|l|}{ Lameta Formation } \\
\hline & Coniacian & & \multicolumn{2}{|l|}{ Coralline Limestone Formation } \\
\hline & \multirow{2}{*}{ Turonian } & Bagh Group & \multirow{2}{*}{ Nodular Limestone Formation } & Chirakhan \\
\hline & & & & Karondia \\
\hline & Cenomanian & 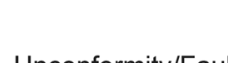 & \multicolumn{2}{|l|}{ Nimar Sandstone Formation } \\
\hline
\end{tabular}

varied palaeontological attributes within the Bagh Group manifests distinct changes in the depositional environment. The rocks are exposed along the northern flank of the Narmada rift basin and occur in patches (Fig. 1). Rocks of the Nimar Sandstone Formation are well exposed in several sections including the Man River near Awaldaman, Sitapuri, Bagh River, Rampura, Bagh Cave, Jobat, and other areas (detail of locations is given in Fig. 1). The Nimar
Sandstone Formation is characterized by conglomerate, arenaceous to arkosic sandstone, sandstone-mudstone heteroliths, and mudstone. In the study area, the general strike of beds is $\mathrm{N} 15^{\circ} \mathrm{E}-\mathrm{S} 15^{\circ} \mathrm{W}$ to $\mathrm{N}-\mathrm{S}$ with a dip of $8^{\circ}-$ $10^{\circ}$. The depositional age of the Nimar Sandstone Formation is considered as Cenomanian (Jaitly and Ajane 2013), which has been determined mostly based on biostratigraphic records preserved in the upper part of the

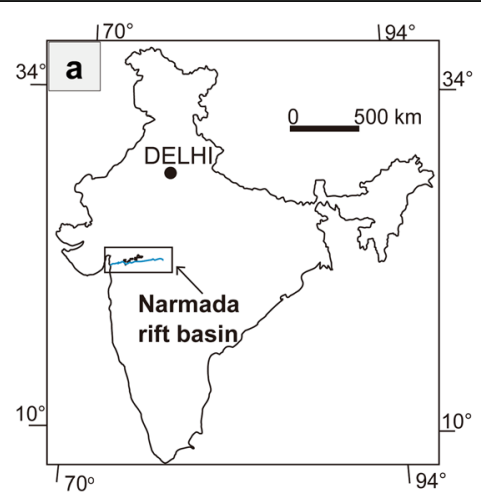

Legends for (b)

$\square$ Cover (Deccan Traps)

Lameta Formation

Coralline Limestone

$\square$ Nodular Limestone

$\square$ Nimar Sandstone

Basement

- City/Town

- Study locations

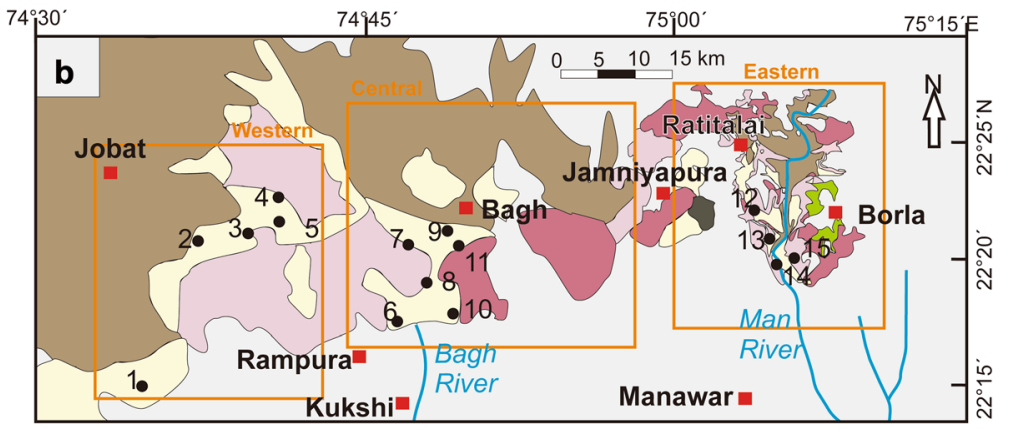

Fig. 1 a Map of India showing location of the Narmada rift basin; b Geological map of the study area (modified after Jaitly and Ajane 2013), showing distribution of the Bagh Group. Black points marked with numbers (1-15) indicate locations/areas of exposed rock sections from where respective vertical sedimentary lithologs were prepared: 1-Phata; 2-Ghoda; 3-Chikapoti; 4-Dhursal; 5-Akhara; 6-Rampura; 7-Baghini Temple; 8Bagh; 9-Neemkheda; 10-Dam; 11-Raisinghpura; 12-Ratitalai; 13-Baria; 14-Man River; 15-Sitapuri 
Table 2 Inferred depositional age of the Nimar Sandstone Formation based on biostratigraphic studies

\begin{tabular}{ll}
\hline Inferred age and the sources & Evidence \\
\hline Cenomanian age for the upper part of the Nimar & Microfaunal foraminiferal assemblage from the upper calcareous portion of the Nimar \\
Sandstone Formation (Chiplonkar and Badve 1973) & $\begin{array}{l}\text { Sandstone Formation: Miliammina manitobensis, Ammobaculites obliquus, Tritaxia ellisore, } \\
\text { T. pyramidata, Textularia angalica, Quinqueloculina semiplana etc.; Occurrence of marker } \\
\text { pre-Cenomanian forms such as Astarte sinuicostata, A. hexicostata, Cardium pharaensis and } \\
\text { Protocardia pondicherriensis }\end{array}$ \\
$\begin{array}{l}\text { Onchopristis indicus sp. (fish tooth) from Oyster bed of the Nimar Sandstone Formation; } \\
\text { Cenomanian (Chiplonkar 1974) }\end{array}$ & $\begin{array}{l}\text { Fragments of Chiplonkarina dimorphopora in the uppermost part of the Nimar Sandstone } \\
\text { Formation }\end{array}$ \\
Cenomanian (Taylor and Badve 1995) & $\begin{array}{l}\text { A diverse assemblage of calcareous algae from the top of the Nimar Sandstone } \\
\text { Formation near Pipaldehla }\end{array}$ \\
Late Turonian-early Coniacian (Jafar 1982) & $\begin{array}{l}\text { Nano-fossils assigned to the Eiffellithus eximius Zone } \\
\text { Plant fossil from the lower fluvial portion }\end{array}$ \\
Early Cretaceous (Murty et al. 1963) & $\begin{array}{l}\text { Palynomorph assemblage: Cyathidites australis, C. minor, Haradisporites mineri, Stereisporites } \\
\text { sp., Cingutriletes sp., Callialisporites dampieri, C. trilobatus, Klausipollenites sp., Alisporites } \\
\text { ovalis, Abiespollenites triangularis, Podocarpidites ellipticus, P. multesimus, Araucariacites } \\
\text { australis, Cycadopites gracilis, C. sakrigaliensis and Striatites sp. in carbonaceous clays from } \\
\text { the lower part of the fluvial portion of the Nimar Sandstone Formation at Umrali village, } \\
\text { Jhabua District }\end{array}$ \\
\hline
\end{tabular}

succession (Table 2). However, data depicting the absolute age of deposition of the Nimar Sandstone Formation is lacking till date.

\section{Material and methods}

Unmetamorphosed, undeformed siliciclastic rocks of the Nimar Sandstone Formation are well exposed in and around the Bagh area (Fig. 1) in the western part of the state of Madhya Pradesh, central India. Well-exposed, long sections are available in the field for detailed sedimentological study. Altogether 15 sections were studied, distributed in three zones in the study area: (i) Awaldaman, Ratitalai, Sitapuri, Baria, etc. in the eastern part, (ii) Bagh, Rampura, Raisinghpura, etc. in the central part, and (iii) Chikapoti, Akhara, Phata, Ghoda, etc. in the western part.

The sedimentological study is primarily based on (i) facies analysis, which includes descriptions and

Table 3 Brief descriptions and interpretations of the facies types within the channel-fill facies association (FA-1)

\begin{tabular}{ll}
\hline Facies types & Description \\
\hline Facies 1A: Clast-supported & Lenticular, clast-supported polymictic conglomerate \\
conglomerate & non-conformably overlying basement rocks; facies \\
& thickness upto $90 \mathrm{~cm}$; clasts vary in composition, \\
& angular to sub-angular, randomly oriented; sandy \\
& matrix.
\end{tabular}

Facies 1B: Matrix-supported Sandy-matrix-rich, texturally immature, lenticular conglomerate

Facies 1C: Pebbly sandstone

Facies 1D: Trough crossstratified sandstone conglomerate, locally interbedded with sandstone; clasts of quartz, jasper, basement rock fragments, and few mud clasts; Clasts sub-rounded, 2-10 cm in diameter, randomly oriented.

Persistently developed in all sections; moderatelysorted, subrounded coarse- to medium-grained sandstone with large-scale trough cross-strata (set thickness $50-55 \mathrm{~cm}$ ) changing to small trough cross-strata (set thickness $20-30 \mathrm{~cm}$ ) near top of beds; facies thickness upto $\sim 2.5 \mathrm{~m}$; angular to sub-angular, poorly-sorted pebble layers separate the sandstone beds.

Medium- to coarse-grained, moderately-sorted, angular to subrounded sandstone with trough cross-strata; local pebble concentration common; small-scale asymmetrical ripples preserved on bed tops; abundant in all sections with thicknesses of $5 \mathrm{~cm}->50 \mathrm{~cm}$.

\section{Interpretation}

Deposited as small channel lag or longitudinal braided bars of low-sinuous streams (Miall 2006; Malaza et al. 2013).

Debris flow deposit (Miall 1982) with scooping of underlying cohesive, unconsolidated mud (Bhattacharya and Bhattacharya 2012).

Alternate pebble-rich and pebble-poor layers indicate alternate high-energy and relatively low-energy conditions, respectively; migration of bars in low-sinuous high-gradient meandering streams (McGowen and Garner 1970; Miall 1982).

Migration of channel bars (Best and Kostaschuk 2002); pebbles indicates fluctuating energy. 
interpretations of facies types and facies associations in the frame of prevalent process-response models and mechanisms of deposition, and (ii) preparation of lithologs from different parts and their correlation to understand the spatio-temporal distribution of different facies types and the depositional conditions.

The sequence-stratigraphic study is primarily based on the identification and interpretation of different stratal stacking patterns, viz., coarsening-up (progradational) and fining-up (retrogradational), in the correlated sections, followed by the interpretation of sediment packages (cycles) of different frequencies.

\section{Results}

\subsection{Sedimentological facies architecture}

Sedimentologically, the siliciclastic succession of the Nimar Sandstone Formation (average 20-30 m thick) is represented by seventeen facies types grouped in five distinct facies associations (FA-1-FA-5). Brief descriptions and interpretations of the facies types in different facies associations are depicted in Tables 3, 4, 5, 6 and 7, respectively. Representative photographs of the facies types of different facies associations (FA-1-FA-5) are represented in Figs. 2, 3, 4, 5 and 6, respectively.

Facies association FA-1 (Fig. 2) consists of four facies types, viz., the clast-supported conglomerate (facies 1A), the matrix-supported conglomerate (facies $1 \mathrm{~B})$, the pebbly sandstone (facies $1 C$ ) and the trough cross-stratified sandstone (facies 1D) (see Table 3). All the facies types are characterized by a very coarse-grained immature nature with an abundance of pebbles. Facies types mostly conform to large channel geometries with occasional sharp erosional basal contacts. The sediment fill pattern in individual channel geometries depicts an abundance of pebbles near the basal part often associated with large trough cross-strata, changing to smaller trough cross-strata in coarse-grained sandstone in the upper part. Overall facies architecture of FA-1 indicates a channel-fill facies association where sedimentation took place as channel-filling basal lag to point bar in a low-sinuosity meandering stream of relatively high energy.
The facies association FA-2 (Table 4; Fig. 3) is characterized by relatively fine-grained rocks. It is consisted of interbedded sandstone-mudstone (facies $2 \mathrm{~A}$ ) and planelaminated sandstone (facies 2B). The facies types are characterized by an overall sheet-like geometry with alternations of thin-bedded, plane-laminated to ripple cross-stratified sandstone grading to mudstone. Such geometry and the close association of this facies association with channel-fill facies association (FA-1) indicate deposition of FA-2 sediments in overbank areas of channels.

The facies types in the facies association FA-3 (Table 5; Fig. 4) include the large-scale trough crossstratified sandstone (facies 3A) and the planar crossstratified sandstone (facies 3B), which characteristically bear mud-draped foresets, and lateral accretion of ripple cross-sets with reactivation surfaces within channel-fill cross-stratified sandstone beds. Such signatures indicate tidal influence (Bhattacharya et al. 2015, 2018) within a fluvial-dominated fluvio-tidal depositional setting.

The facies association FA-4 (Table 6; Fig. 5) consists of five different facies types, namely, the heterolithic sandstone-mudstone (facies $4 \mathrm{~A}$ ), the mud-clast-bearing conglomerate (facies $4 \mathrm{~B}$ ), the plane-laminated sandstone (facies $4 \mathrm{C}$ ), the bioturbated sandstone (facies 4D) and the green sandstone (facies $4 \mathrm{E}$ ). Abundant bi-directional ripple and climbing ripple cross-strata with mud-draped foresets, presence of glauconite in sandstone, trough cross-strata in sandstone with abundant mud, and an abundance of marine invertebrate trace fossils, etc. all indicate a strong tidal control within the fluvial system during the sedimentation of the tide-dominated fluviotidal facies association (FA-4).

The facies association FA-5 (Table 7; Fig. 6) is represented by the fossil-bearing sandstone (facies 5A), the Thalassinoides-Ophiomorpha-bearing thinly-laminated sandstone-mudstone (facies 5B), the wave-ripplebearing sandstone (facies $5 \mathrm{C}$ ) and the massive mudstone (facies 5D). The abundance of symmetrical wave ripples, presence of marine invertebrate fossils and trace fossils, and the prevalence of both sand and mud are the characteristics of this facies association, which

Table 4 Brief descriptions and interpretations of facies types within the overbank facies association (FA-2)

\begin{tabular}{|c|c|c|}
\hline Facies types & Description & Interpretation \\
\hline $\begin{array}{l}\text { Facies 2A: Interbedded } \\
\text { sandstone-mudstone }\end{array}$ & $\begin{array}{l}\text { Laterally persistent, alternate thick to thin sandstone } \\
\text { grading to red mudstone beds; sheet-like geometry; } \\
\text { crude plane laminations in sandstone. }\end{array}$ & $\begin{array}{l}\text { Alternate traction and suspension load deposition } \\
\text { under relatively low-energy conditions (Reineck and } \\
\text { Singh 1980); sheet-like geometry indicates an } \\
\text { overbank setting (Leopold and Wolman 1957). }\end{array}$ \\
\hline $\begin{array}{l}\text { Facies 2B: Plane-laminated } \\
\text { sandstone }\end{array}$ & $\begin{array}{l}\text { Plane-laminated, fine- to medium-grained sandstone } \\
\text { beds, few cm to more than } 10 \mathrm{~cm} \text { in thickness; planar } \\
\text { bedding show parting lineation; well sorted, subrounded } \\
\text { to rounded quartz with few plagioclase feldspar and } \\
\text { lithic fragments; small current ripples on top surface } \\
\text { of beds; bioturbation by Skolithos isp. Common. }\end{array}$ & $\begin{array}{l}\text { Plane-laminated sandstone with parting lineations } \\
\text { indicates supercritical upper flow regime } \\
\text { (Paola et al. 1989), possible during peak flood } \\
\text { time (Miall 1977); ripples near top of beds indicate } \\
\text { subcritical flow in shallow channels (Paola et al. 1989). }\end{array}$ \\
\hline
\end{tabular}


Table 5 Brief descriptions and interpretation of facies types within the fluvial-dominated fluvio-tidal facies association (FA-3)

\begin{tabular}{|c|c|c|}
\hline Facies types & Description & Interpretation \\
\hline $\begin{array}{l}\text { Facies 3A: Large-scale trough } \\
\text { cross-stratified sandstone }\end{array}$ & $\begin{array}{l}\text { Metre-scale trough cross-strata in medium-grained, } \\
\text { moderately-sorted sandstone; grains subrounded; } \\
\text { bed thickness } 20-50 \mathrm{~cm} \text {; thickness of cross-strata } \\
\text { sets }>30 \mathrm{~cm} \text {; normal grading in cross-strata set; } \\
\text { mud-draped foresets with lateral accretion; } \\
\text { convolute laminations present locally. }\end{array}$ & $\begin{array}{l}\text { Large-scale trough cross-strata with lateral accretion and } \\
\text { mud-draped foresets indicate migration of bars by tidal } \\
\text { currents (Bose and Das 1986); convolute laminae indicate } \\
\text { liquefaction and fluidization during deposition } \\
\text { (Jha et al. 2017). }\end{array}$ \\
\hline $\begin{array}{l}\text { Facies 3B: Planar cross-stratified } \\
\text { sandstone }\end{array}$ & $\begin{array}{l}\text { Lenticular-shaped, medium- to coarse-grained, } \\
\text { tabular planar cross-stratified sandstone with } \\
\text { locally dispersed pebble layers; thickness of } \\
\text { cross-bed sets } 10-35 \mathrm{~cm} \text {; each set records } \\
\text { coarse- to medium-grained sandstone near } \\
\text { base grading into fine-grained sandstone; } \\
\text { thin mud veneers present on foresets. }\end{array}$ & $\begin{array}{l}\text { Downstream migration of 2-D ripples under lower } \\
\text { flow-regime (Harms et al. 1982) in channel bar; thin } \\
\text { mud veneers indicate tidal fluctuations. }\end{array}$ \\
\hline
\end{tabular}

Table 6 Brief descriptions and interpretation of facies types under the tide-dominated fluvio-tidal facies association (FA-4)

\section{Facies types}

Facies 4A: Heterolithic sandstone-mudstone

Facies 4B: Mud-clastbearing conglomerate

Facies 4C: Planelaminated sandstone

Facies 4D: Bioturbated sandstone

Facies 4E: Green sandstone

\section{Description}

2-10-cm-thick, fine- to medium-grained, moderatelysorted sandstone alternating with thick, massive to laminated mudstone; sandstone beds characterized by ripple cross-strata with mud-draped foresets and lateral accretion against frequent reactivation surfaces, sigmoidal cross-strata, bi-directional ripple cross-laminae, climbing ripples with sinuous, bifurcated crests, and broad-crested symmetrical wave ripples; mud-dominated units characterized by wavy to lenticular bedding; bed thickness 5-20 cm; sand lenses 2-4 cm in thickness, asymmetrical and discontinuous with internal muddraped laminae become continuous up-section; thin interbedded mudstone and fine-grained, plane-laminated sandstone laminae also present, with sandstone laminae thickness 1-8 $\mathrm{mm}$ and mudstone laminae thickness $0.5-2 \mathrm{~mm}$.

Lenticular, sharp (erosional) based conglomerate with mud clasts; bed thickness 5-10 cm; Size of the mud clasts $0.2-3 \mathrm{~cm}$ with frequent bending; angular to subangular mud clasts show yellow to brown, faded violet, and white colour.

Fine-grained plane-laminated sandstone beds (bed thickness of 2-25 cm) with intermittent thin, impersistent mudstone layers; soft-sediment deformation structures (SSDS) such as convolute laminae, load and flame structures.

Medium- to coarse-grained, crudely laminated sandstone with subangular grains; thickness $40 \mathrm{~cm}-2.5 \mathrm{~m}$, increasing in the west than in the east; laminae partly destroyed by bioturbation; diversity and intensity of bioturbation increase towards west; vertical and horizontal U-shaped, Y-shaped and J-shaped burrows of Thalassinoides and Ophiomorpha, with subordinate Planolites, Skolithos, Palaeophycus, Arenicolites and Rosselia; concentration of various shell fragments along with microscopic bivalve shells.

Coarse-grained, well-sorted and rounded, massive, green sandstone; predominates in the western part of the study area; locally, small trough cross-strata present; facies thickness 0.4-2 m; glauconite abundant.

\section{Interpretation}

Mutually opposite cross-strata set indicate tidal fluctuations (Klein 1971; Boersma and Terwindt 1981; Elliott 1986); symmetrical ripples and combined flow ripples manifest interference of tides and waves; wavy and lenticular beddings indicate pronounced suspension fall-out over alternate traction current; alternation of laminated sandstone-mudstone indicates tidal inclined heterolithic strata (IHS) in lowenergy tidal setting (Reineck and Wunderlich 1967, 1969; Reineck and Singh 1980; Choi et al. 2004; Choi 2010).

Scouring of mud from underlying unconsolidated mud bed by high-energy current/wave and rapid deposition without significant transportation (Bhattacharya and Bhattacharya 2012; Eide et al. 2016).

Suspension deposit during slack phase (Reineck and Singh 1980); SSDS indicates density contrast among the litho-units during deposition (Jha et al. 2017).

Intense bioturbation indicates nutrient-rich, oxygenated conditions during deposition; burrowing by ThalassinoidesOphiomorpha dominated ichnoassemblage indicates a nearshore setting (Buatois and Mángano 2011).

Deposition from to-and-fro movements of sand grains by shallow marine waves; glauconite also indicates shallow marine condition. 
Table 7 Brief descriptions and interpretation of facies types under the shoreface facies association (FA-5)

\begin{tabular}{lll}
\hline Facies types & Description & Interpretation \\
\hline Facies 5A: Fossil-bearing & Fine- to medium-grained sandstone with local & Association of Turritella and Cardium shells indicates \\
sandstone & pebble layers; gastropods (Turritella) with bivalve & shallow marine depositional conditions. The \\
& (Cardium) near base; dominance of bivalves & abundance of Turritella indicates well-oxygenated, \\
increases up-section; Gastropod shells often & nutrient-rich, warm water conditions (Malarkodi \\
mutually oppositely oriented; symmetrical & et al. 2009). Ostrea abundantly lives in bays and \\
& low-amplitude long wave-length ripples, & estuaries and/or in nearshore subtidal environments \\
& ladder-back ripples and flat-topped ripples & (Khosla and Sahni 2000). Small symmetrical ripples \\
with bifurcated crest lines; near the upper & indicate wave activity in shallow waters (Bhattacharya \\
part shells of the oyster Ostrea (height & and Jha 2014).
\end{tabular}

Facies 5B: ThalassinoidesOphiomorpha-bearing thinlylaminated sandstone-mudstone

Facies 5C: Wave-ripple-bearing sandstone

Facies 5D: Massive mudstone
Red, thinly-laminated sandstone-mudstone alternations, with alternate bioturbated and non-bioturbated units; primary laminae disturbed by abundant large Thalassinoides and Ophiomorpha burrows; thin laminae in mudstone; small symmetrical ripple on sandstone beds.

Coarse-grained, moderately sorted sandstone with subrounded grains; thickness of beds $10-15 \mathrm{~cm}$; flat-topped symmetrical ripples with continuous, bifurcated crests on sandstone beds; smaller ladder-back ripples in the troughs of the major ripples; chevronshaped internal laminae with irregular bottom set.

Red, friable, thick $(6-120 \mathrm{~cm})$ mudstone devoid of sedimentary structures; quartz, dark opaque minerals, and mica, with unaltered to partly-altered feldspar grains; well-developed near Sitapuri; bioturbation not observed; sharp contact with the overlying Nodular Limestone Formation.
Thick mudstone alternating with fine-grained sandstone indicates low-energy conditions (Reineck and Singh 1980); intense bioturbation (Thalassinoides and Ophiomorpha) indicates oxygenated, nutrient-rich shallow marine environments; small, symmetrical ripples indicate reworking by waves.

Coarse grain size and symmetrical ripples with chevron laminae indicate moderate-energy wave conditions (Harms et al. 1975).

Suspension fallout of fine sediments under very low energy conditions; absence of bioturbation indicates relatively anoxic conditions and an increased water depth.
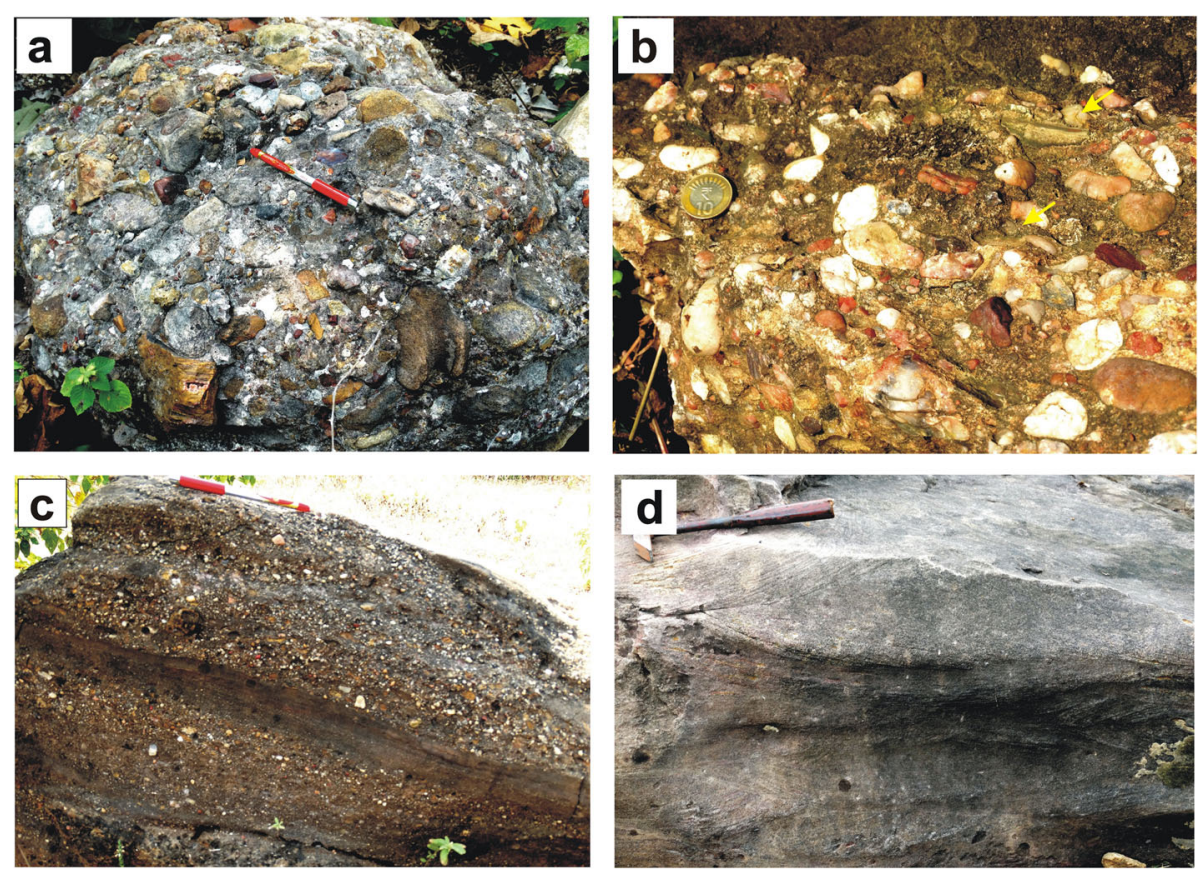

Fig. 2 Field photographs. a Clast-supported conglomerate (facies 1A) showing angular to sub-angular clasts of basement gneissic rock, exposed in the Rampura section. Length of pen is $14.5 \mathrm{~cm}$. b Matrix-supported conglomerate (facies 1B), exposed in Bagh section. Arrows indicate occurrence of mud clasts. Diameter of coin is $2.5 \mathrm{~cm}$. c Pebbly sandstone (facies $1 \mathrm{C}$ ) showing alternate pebble-rich and pebble-free sandstone beds, exposed in the Neemkheda section. Length of pen is $15 \mathrm{~cm}$. $\mathbf{d}$ Trough cross-stratified sandstone (facies 1D), exposed along the river bank of Baria section. Length of hammer is $30.5 \mathrm{~cm}$ 

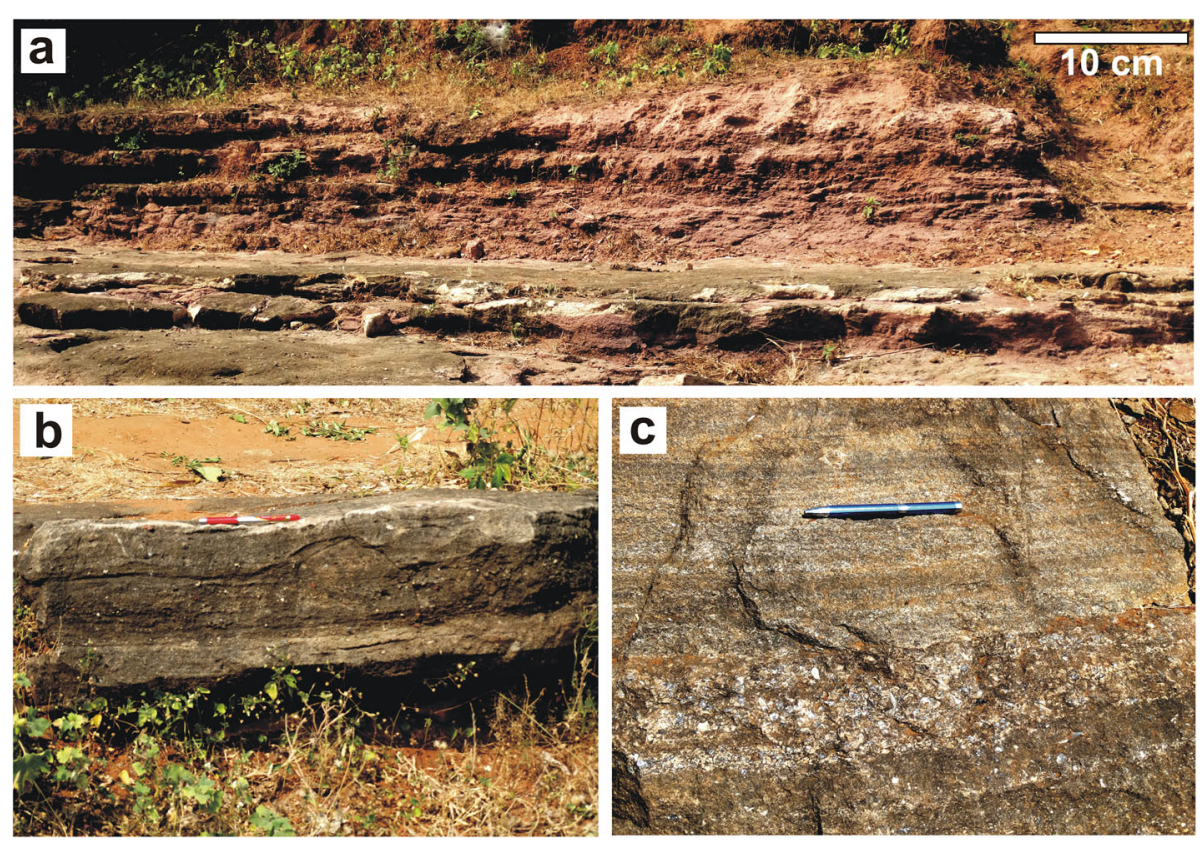

Fig. 3 a Field photograph of interbedded sandstone-mudstone (facies 2A), near Raisinghpura. b Field photograph of the plane-laminated sandstone (facies 2B), Man River section. Length of pen is $14.5 \mathrm{~cm}$. c Cross-section of the plane-laminated sandstone facies showing welldeveloped plane beds. Length of pen is $15 \mathrm{~cm}$

together indicate a significant amount of wave influence during deposition of the shoreface facies association (FA-5).

Detailed vertical sedimentary logs, showing the occurrence of facies types and facies associations in the 15 sections, from the western, central, and eastern parts of the study area are presented in Figs. 7, 8 and 9, respectively. These logs reveal that - i) the lower part of the succession is mostly comprised of immature sediments of FA-1and FA2 , and is overlain by

ii) sediments of the fluvial-dominated fluvio-tidal facies association (FA-3), gradually changing vertically and laterally into sediments of the tide-dominated fluviotidal facies association (FA-4), commonly occupying the middle part of the succession and, finally,
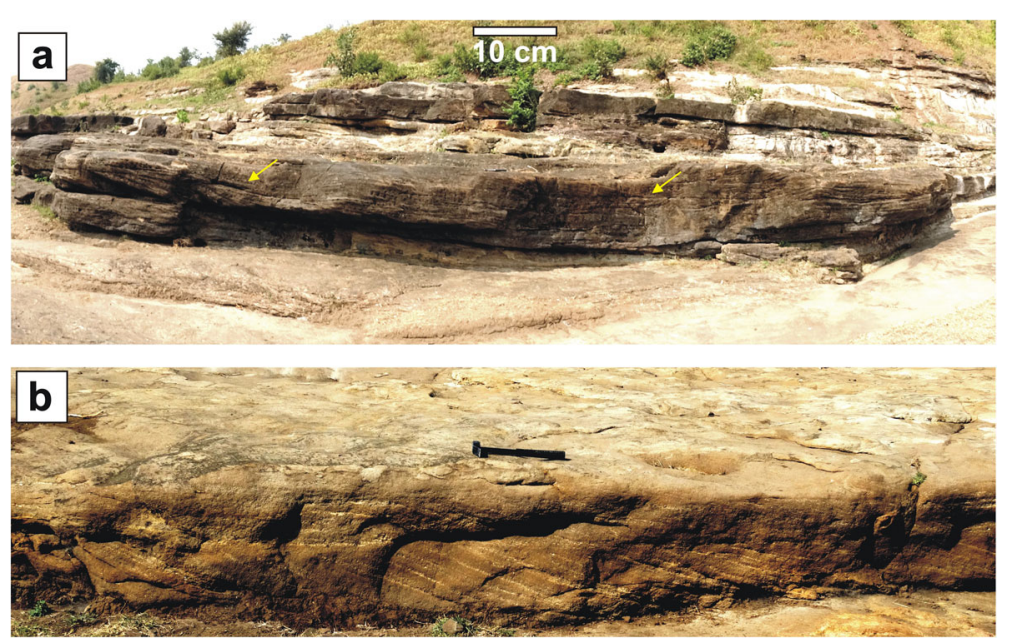

Fig. 4 a Field photographs of large-scale trough cross-stratified sandstone (facies 3A) along the western bank of the Man River section. Arrows show lateral accretion surfaces. b Field photograph of planar cross-stratified sandstone (facies 3B), Man River section. Length of hammer is $30.5 \mathrm{~cm}$ 

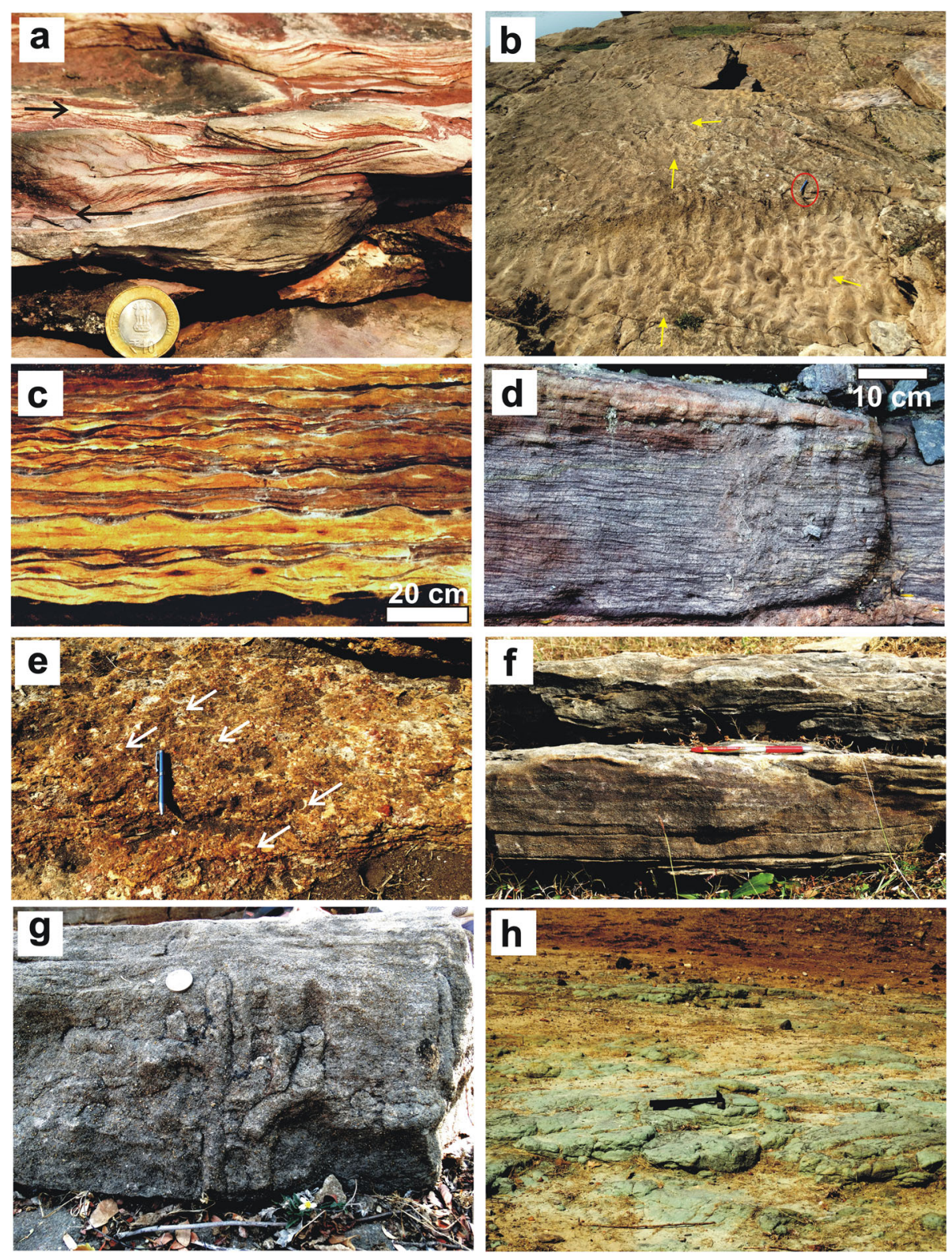

Fig. 5 Field photographs. a Heterolithic sandstone-mudstone (facies $4 A$ ) showing presence of mud drapes and poorly-developed bidirectional cross-strata, Man River section. The arrows indicate apparent orientation of the foresets in adjacent cross-strata sets. Diameter of coin is $2.5 \mathrm{~cm}$. $\mathbf{b}$ Interference ripples with bifurcation of crest line (yellow arrows) on the sandstone bedding surface of facies $4 \mathrm{~A}$, Man River section. Length of pen (encircled) is $14.5 \mathrm{~cm}$. c Lenticular and wavy bedding developed within facies 4A, preserved in Bagh Cave. d Inclined heterolithic strata developed within facies 4A, Man River section. e Mud-clast-bearing conglomerate (facies 4B) showing angular mud clasts (arrows), Man River section. Length of pen is $14.5 \mathrm{~cm}$. f Plane-laminated sandstone (facies 4C), Ratitalai section. Length of the pen is $14.5 \mathrm{~cm}$. g Bioturbated sandstone (facies 4D), Akhara section. Diameter of coin is $2.5 \mathrm{~cm}$. $\mathbf{h}$ Green sandstone facies (4E), exposed in Ghoda area. Length of hammer is $30.5 \mathrm{~cm}$

iii) sediments of the shoreface facies association (FA-5) predominate along with tide-dominated facies associations (mostly FA-4) in the upper part of the succession.

At different stratigraphic levels in the middle part of the studied succession, layers with various soft-sediment deformation structures (SSDS), e.g., convoluted laminae, pseudo-nodules, load and flame structures, synsedimentary faults, slumps, and sand dykes, have been recorded by Jha et al. (2017).

Alternate fluvial (FA-1 and FA-2) and fluvialdominated tidally-influenced sediments (FA-3) 

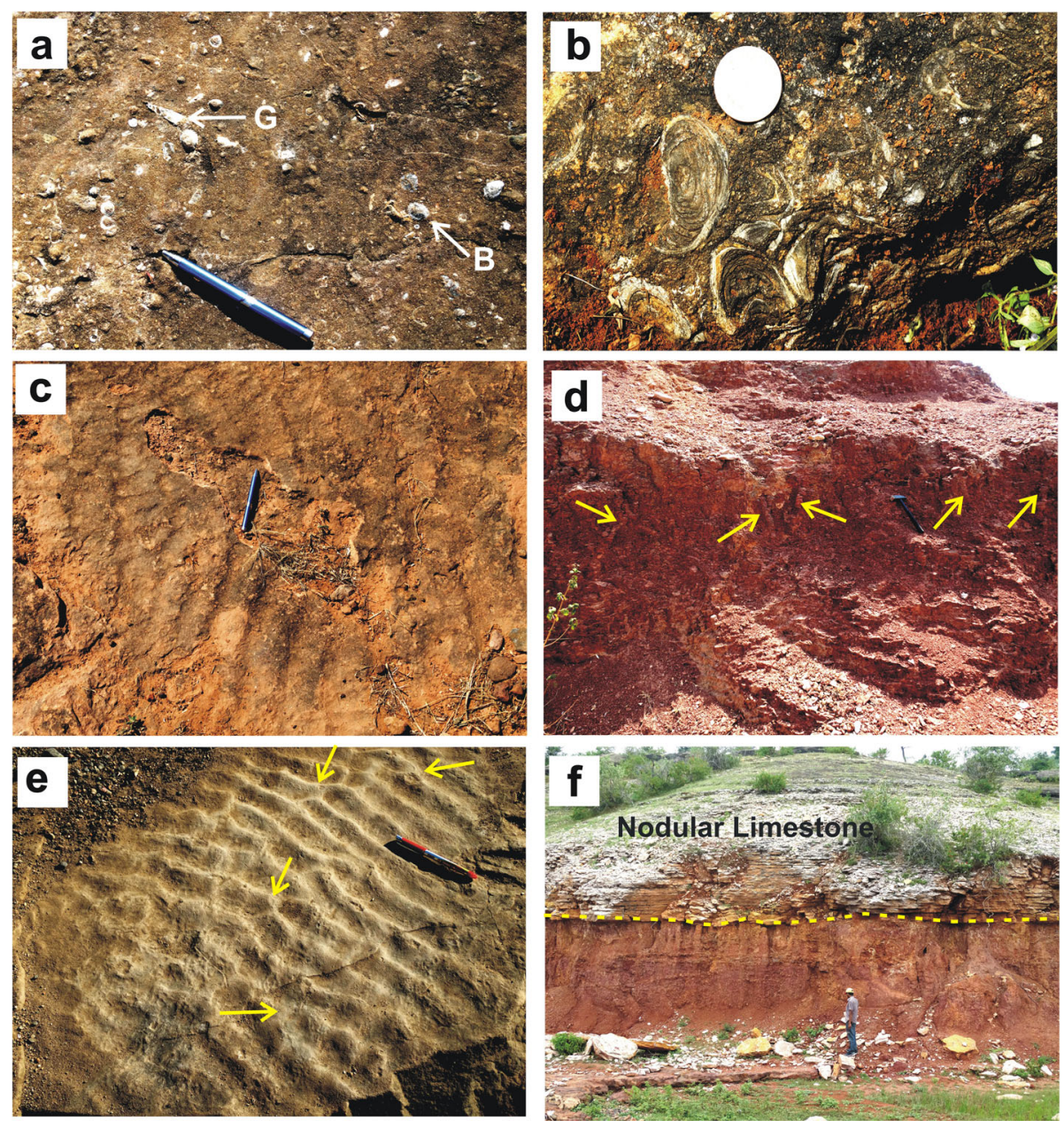

Fig. 6 Field photographs. a Fossil-bearing sandstone (facies $5 \mathrm{~A}$ ) showing gastropod (G) and bivalve shells (B) on sandstone bedding plane, near Akhara. Length of pen is $14.5 \mathrm{~cm}$. b Ostrea shells in facies $5 \mathrm{~A}$, occurring near the Bagh-Akhara road. Diameter of coin is $2.5 \mathrm{~cm}$. c Symmetrical flattopped wave ripples with small-scale ladder-back ripples in facies 5A, preserved near Akhara. Length of pen is $14.5 \mathrm{~cm}$. $\mathbf{d}$ ThalassinoidesOphiomorpha-bearing thinly-laminated sandstone-mudstone (facies 5B) showing well-preserved vertical burrows (arrows). The section is exposed near Sitapuri. Length of hammer is $30.5 \mathrm{~cm}$. e Wave-ripple-bearing sandstone (facies 5C) showing symmetrical wave ripples with bifurcating crests (arrows), exposed in the Dam section. Length of pen is $14.5 \mathrm{~cm}$. $\mathbf{f}$ Massive mudstone (facies 5D) overlain by white-coloured Nodular Limestone Formation, north of Sitapuri. The contact is marked by dashed yellow line. Man for scale is $170 \mathrm{~cm}$ tall

followed by tide-dominated wave-reworked sediments (FA-4 and FA-5) constitute distinct depositional cycles within a mixed fluvio-marine depositional setting. Cyclic occurrences of the tidally-influenced sediments of FA-4, overlain by the wave-dominated sediments of FA-5 in the middle-upper part of the succession indicate repeated changes in water-depth over short intervals under a tidal to wave interactive system as a product of periodic marine inundations and intercalations. Such repetitive fining-up cycles indicate the inundation of fluvio-tidal channels by marine waters within a typical estuarine setting (Nichols 2009). In the study area, overall dominance of tidal features over wave features points to a tide-dominated waveinfluenced estuary (Jha et al. 2017).
The overall fining-up character, increasing marine dominance up-section, and prevalence of landward palaeocurrent directions indicate an estuarine setting. Within the fluvio-marine interactive setting, three major sub-environments are envisaged:

i) A fluvial-dominated zone initially, with the transition from fluvial channels (FA-1) to floodplain (FA-2), with few tide-affected fluvial deposits (FA-3) in the basal part of the succession, mainly prevails in the eastern and central part of the study area.

ii) A mixed-energy central estuary zone in the middle-upper part of the succession, which consists of transitional fluvio-tidal channels (FA-3) and 


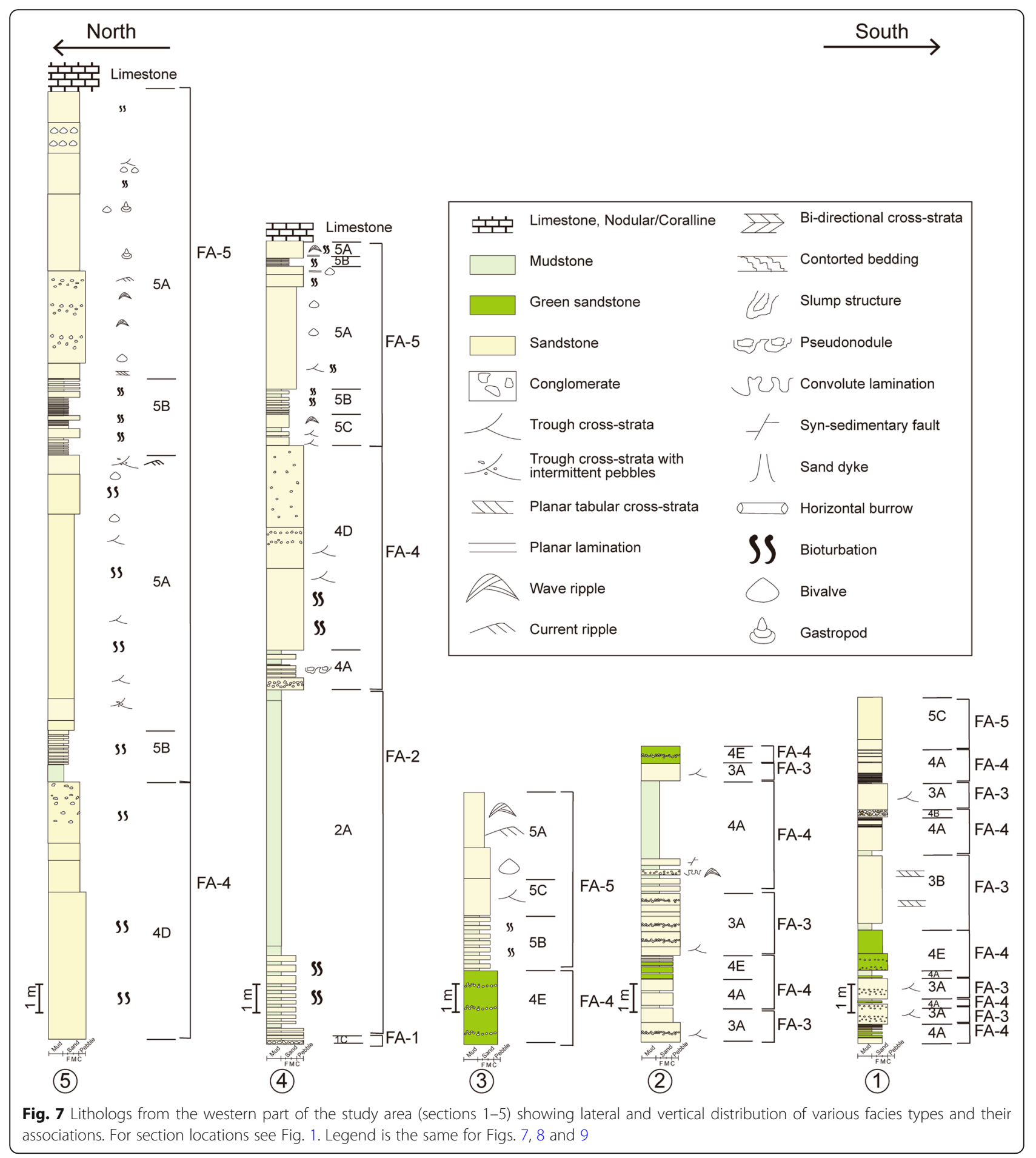

tidal flats associated with tidal channels and bars (FA-4) overlying the fluvial systems in the study area.

iii) A wave-dominated shore environment in the outer estuary zone (top part of FA-4 with FA-5), occupying the upper part of the succession, occurs dominantly in the west and central part and gradually diminishes towards the eastern part of the study area.

The distinct layers with abundant SSDS have been interpreted as seismites by Jha et al. (2017). The 


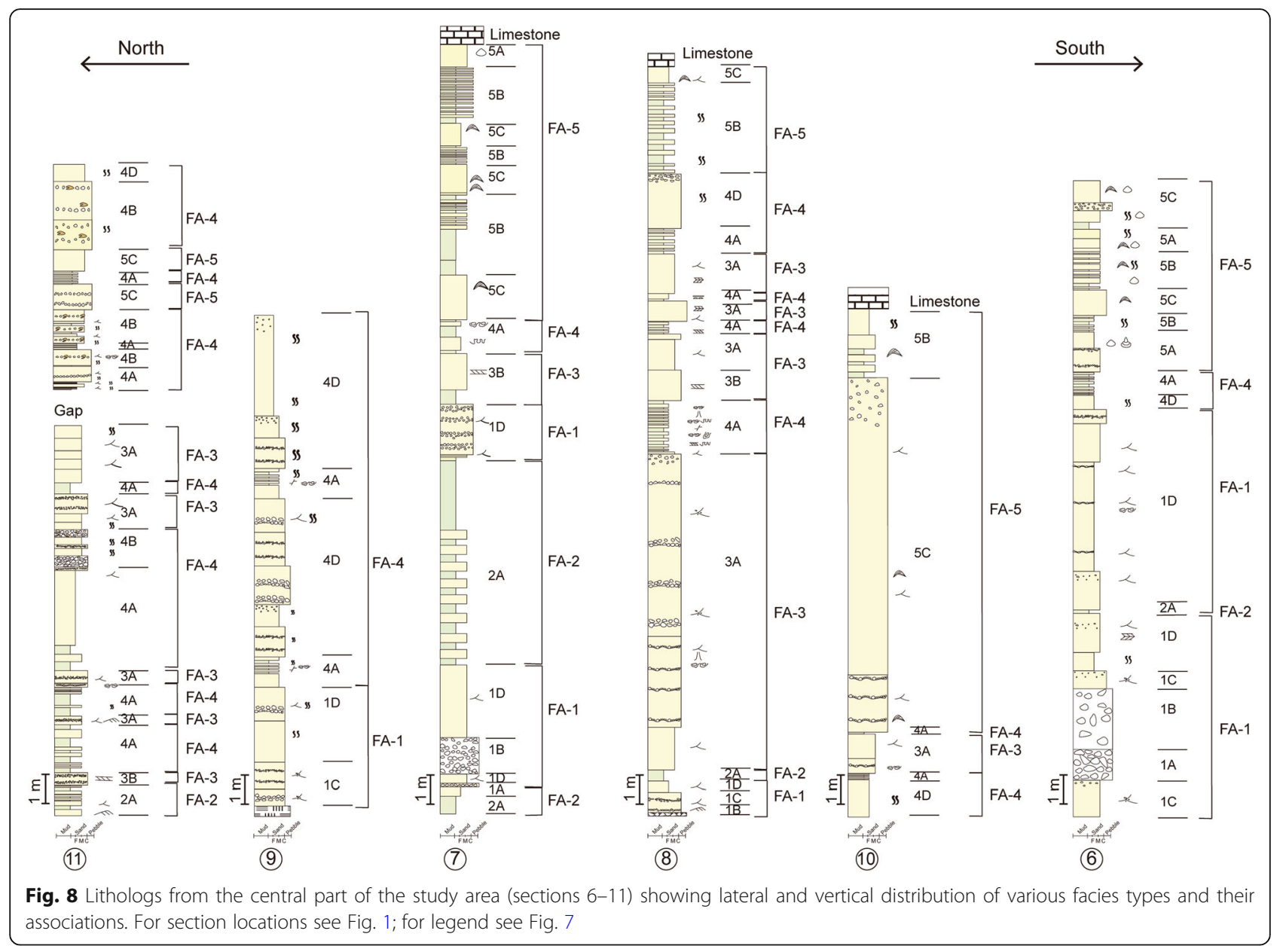

seismite layers mark phases of a substantial shift in depositional conditions from fluvial-dominated to a transgressive tidal- and wave-influenced estuarine system related to basinal subsidence caused by reactivation of the Son-Narmada South Fault during sedimentation of the Nimar Sandstone Formation (Jha et al. 2017).

\subsection{Stratal stacking patterns and T-R cycles}

Vertical and lateral distributions of the litho-units depict an overall fining-upward retrogradational cycle for the entire Nimar Sandstone Formation. Four section correlations are made: (i) in the Akhara-Phata area, the westernmost of the basin, incorporating sections 1-5 (Fig. 10); (ii) in the Bagh area, the central of the basin, incorporating sections 6-11 (Fig. 11); (iii) in the Man River-Ratitalai area, the easternmost of the study area, including sections 12-15 (Fig. 12); and (iv) along a nearly dip-parallel section over the whole study area (Fig. 13), incorporating, from west to east, logs of Chikapoti, Akhara, Bagh, Raisinghpura, and Sitapuri. The correlations provide clear evidence of stratal stacking patterns along the length $(\mathrm{W}-\mathrm{E})$ and width $(\mathrm{N}-$ $\mathrm{S})$ of the basin, and reflect the dominance of marineinfluenced facies types in the western logs in comparison to the easternmost ones. Similarly, a gradual diminishing abundance of channel-fill facies types (mostly FA-1) is observed from east to west in the study area. Within the overall fining-up trend, high-frequency alternate coarsening-up (progradational) and fining-up (retrogradational) hemicycles a are visible in almost all the lithologs (Figs. 10, 11, 12 and 13).

The overall retrogradational pattern with the gradual changeover from dominant fluvial systems in the lower part, followed by mixed fluvial-tidal systems in the middle part and mixed tidal- and wave-dominated open marine systems in the upper part of the studied succession points to the overall transgressive nature of the succession. The transgressive succession is also evident from the systematic change in abundance of fluvial to marine facies from east to west, which signifies a westto eastward marine incursion controlling the sedimentation at different areas. The smaller coarsening- and fining-up hemicycles embedded within this major 


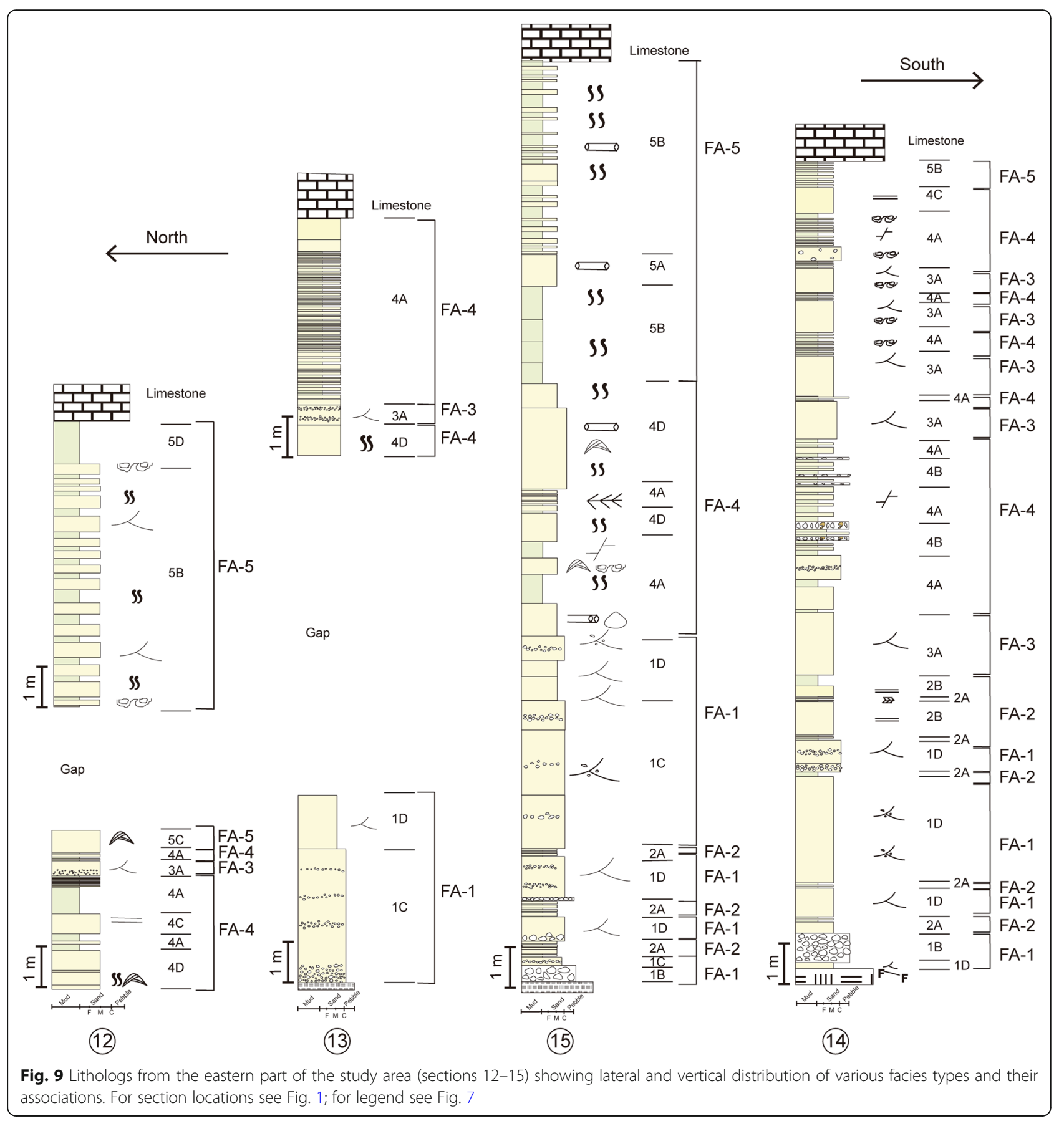

transgressive cycle manifest high-frequency changes in base level and accommodation.

The Nimar Sandstone Formation is conformably overlain by the Nodular Limestone Formation without any visible break in sedimentation. The Nodular Limestone Formation has been interpreted as a restricted shallow marine platform-tidal flat deposit (Ruidas et al. 2018; Bansal et al. 2019). Thus, it remains inconclusive at this stage whether the major transgressive event that affected the entire Nimar Sandstone Formation succession also continued during the deposition of the overlying limestone units.

\subsection{High-frequency T-R cycles}

Four distinct high-frequency hemicycles (Figs. 10, 11, 12, 13, 14 and 15) are observed within the major transgressive cycle: (i) the lowermost coarsening-up hemicycle (named as L-C), followed up by (ii) a fining-up hemicycle (named as L-F) in the lower-middle part of the succession, (iii) another coarsening-up hemicycle 


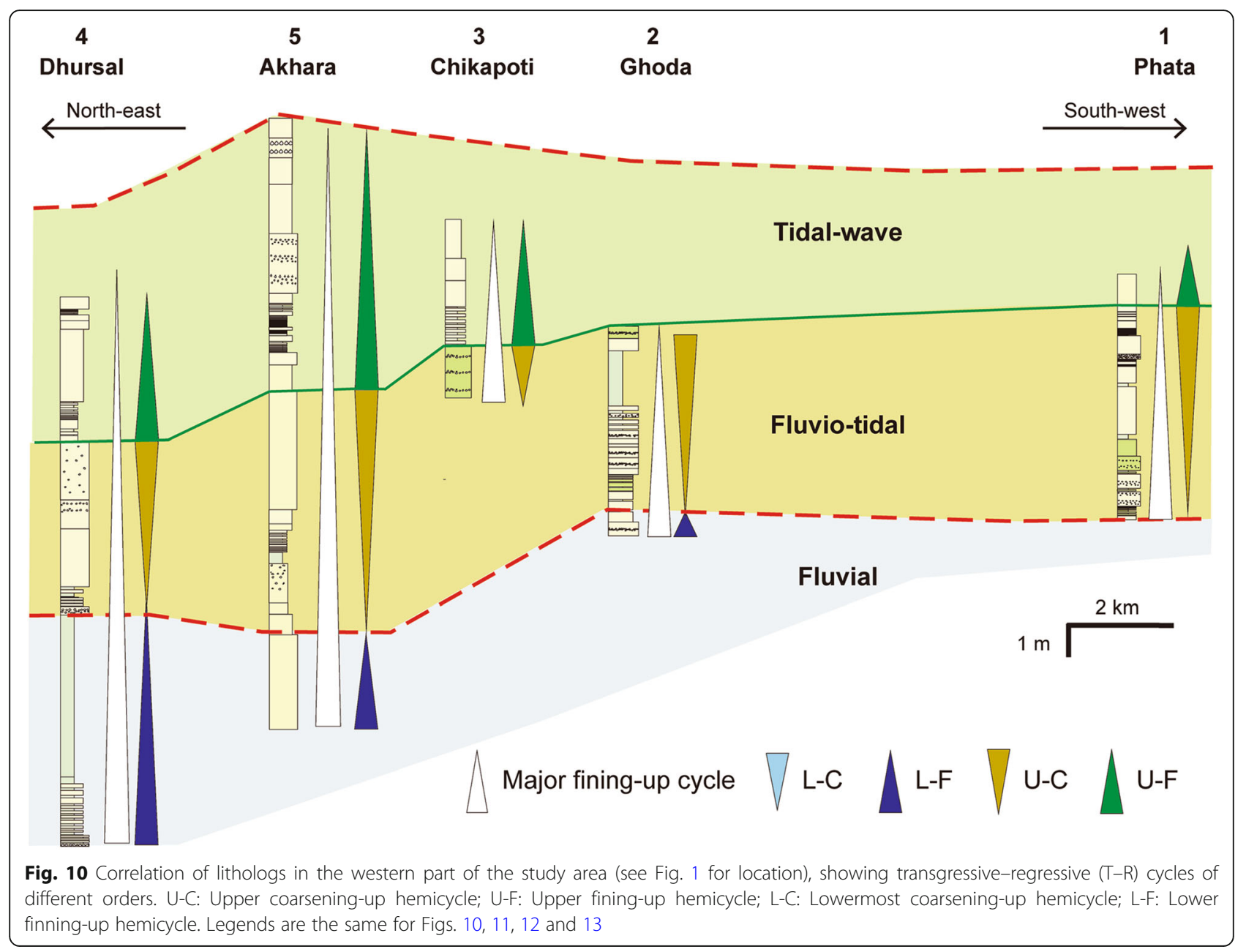

(named as U-C) in the middle-upper part of the succession, and (iv) an upper fining-up hemicycle (named as UF) occurring near the top of the entire succession.

The lowermost coarsening-up (progradational) hemicycle $(\mathrm{L}-\mathrm{C})$ is most prevalent in the central and eastern part of the area (Figs. 11, 12) and depict a stratal stacking pattern formed by the lateral and vertical amalgamation of channel-fill deposits (FA-1), intermittently separated by overbank deposits (FA-2). Overall, FA-1 sediments are much more abundant than FA-2 sediments.

A fining-up (retrogradational) hemicycle (L-F) commonly overlies the L-C hemicycle and occupies the lower to middle part of the succession in the central and eastern parts of the study area (Figs. 11, 12 and 13). However, in the western part, the $\mathrm{L}-\mathrm{C}$ hemicycle is absent and the succession starts with the L-F hemicycle (Fig. 10). This fining-up succession shows a stratal stacking pattern formed predominantly by overbank deposits (FA-2) with isolated, detached units of channel-fill sediments (FA-1). Overall, the overbank deposits are more abundant than the channel-fill sediments within this hemicycle.
Both L-C and L-F are overlain by another coarsening-up (progradational) hemicycle (U-C), mostly occupying the middle to upper part of the succession. The stratal architecture within this hemicycle depicts a progradational stacking pattern with successively stacked fluvial-dominated fluvio-tidal deposits (FA-3) and intermittent finer-grained tidedominated fluvio-tidal deposits (FA-4) (Fig. 15). Both the channel and the overbank deposits are characterized by abundant tidal signatures. Preserved tidal signatures help to differentiate this hemicycle from earlier hemicycles apart from the change in stacking pattern from fining-up below to coarsening-up above. The coarsening-up stacking pattern is produced by the local amalgamation of tide-affected fluvial channels in the middle and upper part of the U-C hemicycle.

The topmost fining-up hemicycle (U-F) caps the earlier hemicycles throughout the entire area. A fining-up, retrogradational stratal stacking pattern is observed with an abundance of FA- 4 facies types accompanied by FA- 5 


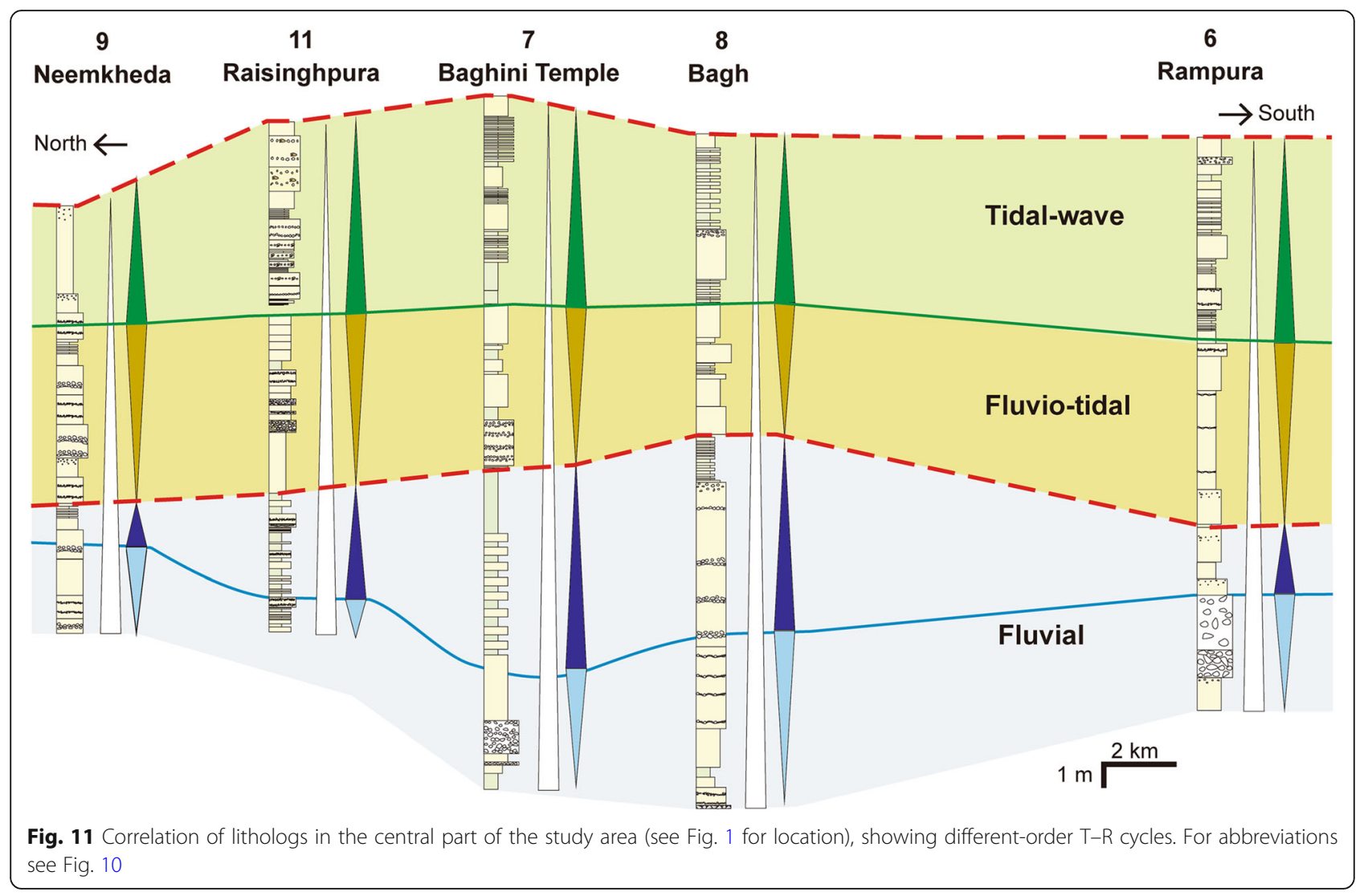

facies types. Marine depositional signatures are most prevalent within this hemicycle in comparison to all other hemicycles, which include sheet sandstone bodies with abundant wave-produced features, heterolithic units with shallow-marine invertebrate fossils and trace fossils, and thick- to thin-bedded tidal heteroliths. Evidence of fluvial sedimentary processes in terms of facies types of FA-1, FA-2 or FA-3 are lacking or absent within this hemicycle. The thickness of the sediment package of U-F also varies significantly, with maximum thickness and sand-rich composition in the western part, and a gradually diminishing thickness and change to a mudrich composition towards the east. This hemicycle is directly overlain by the Nodular Limestone Formation.

\section{Discussion}

\subsection{Interpretation of the high-frequency T-R cycles}

The lowermost coarsening-upward hemicycle (L-C), characterized by highly amalgamated channel-fill units and a high channel/overbank sediment ratio, signifies deposition in unconfined fluvial channels without any connection to marine processes. Lateral and vertical shifts in channel stacking pattern and amalgamation indicate frequent channel avulsion with a significantly low rate of aggradation of overbank deposits. The overall stratal stacking pattern points to a high-amalgamation systems tract (HAST) developed in a lowaccommodation, upstream-controlled fluvial depositional system (Catuneanu 2017).

The overlying fining-up hemicycle (L-F), characterized by stacking pattern dominated by overbank deposits and a low channel/overbank sediment ratio, signifies deposition in confined isolated channels with a low rate of channel avulsion or migration and a high rate of overbank aggradation. Such a stratal stacking pattern is identified as a low-amalgamation systems tract (LAST) (Catuneanu 2017), indicating high accommodation due to basinal subsidence and raised river profile leading to flooding and deposition of finer overbank deposits over the earlier sand-depositing areas. This led to a fining-up retrogradational succession (FA-2 over FA-1) in most areas. The predominance of mud-rich floodplain deposits manifests rising base level conditions, leading to: (i) raising of the river profile, (ii) more deposition than the incision, and (iii) low channel avulsion and aggradation. Such rising of the base level can be considered as an indirect effect of the rising and encroaching sea, which was not far away. Close overlap of this hemicycle by the overlying tide-dominated facies association supports this interpretation.

The stratal stacking pattern and the associated facies architecture in the overlying hemicycles (U-C and U-F) 


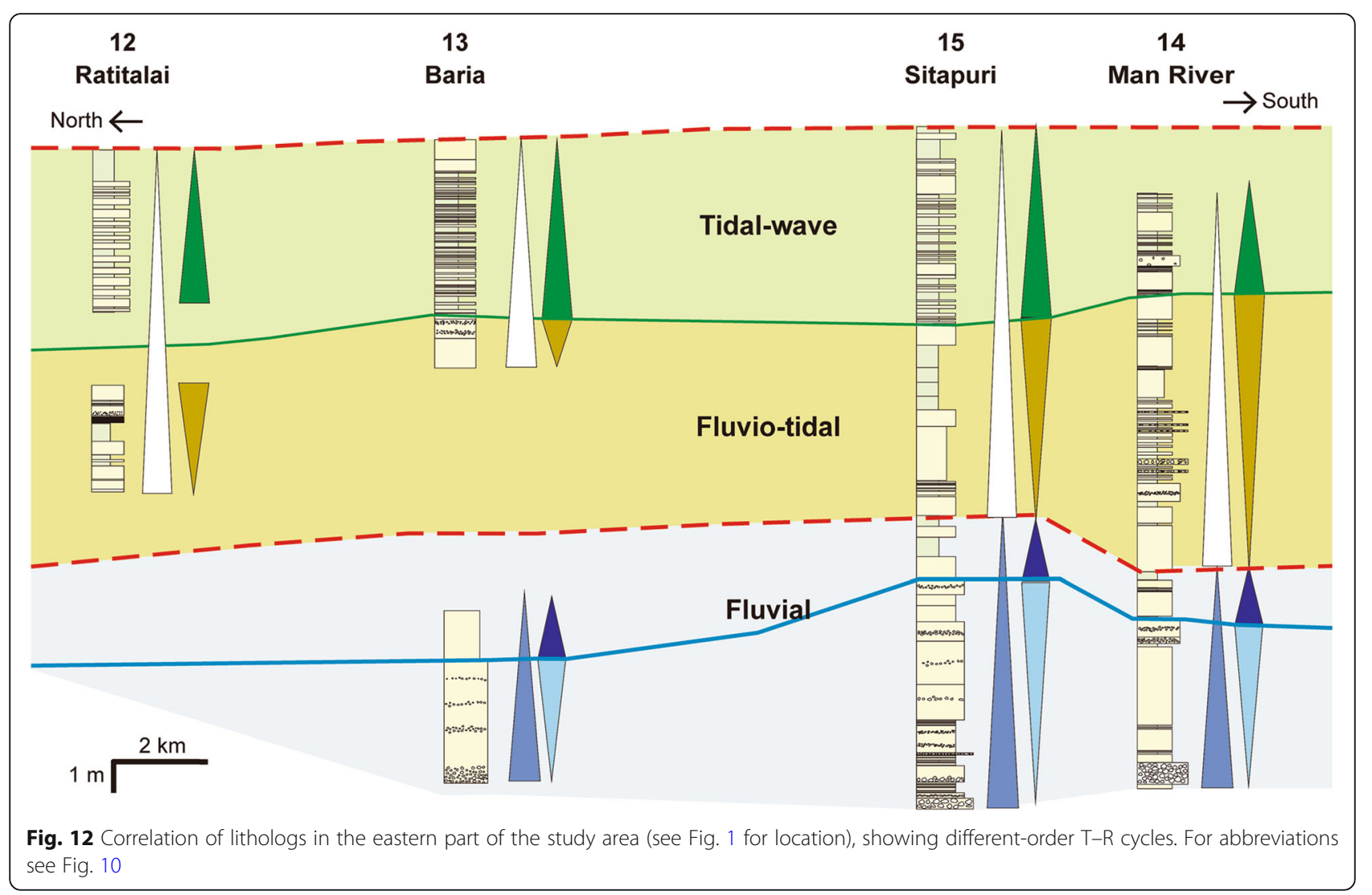

indicate clear signatures of marine influence. Thus, a shift in the depositional conditions from an upstreamcontrolled fluvial setting to a downstream-controlled, marine-influenced transitional setting can be envisaged at the boundary of the L-F hemicycle and the U-C hemicycle. Significant marine influence, in association with basinal tectonics and sediment supply controlled the creation of net accommodation and the resultant stratal stacking patterns. SSDS-bearing beds both above and below the said transition are interpreted as seismites (Jha et al. 2017), which signifies strong control of the basinal tectonism caused by reactivation of faults and

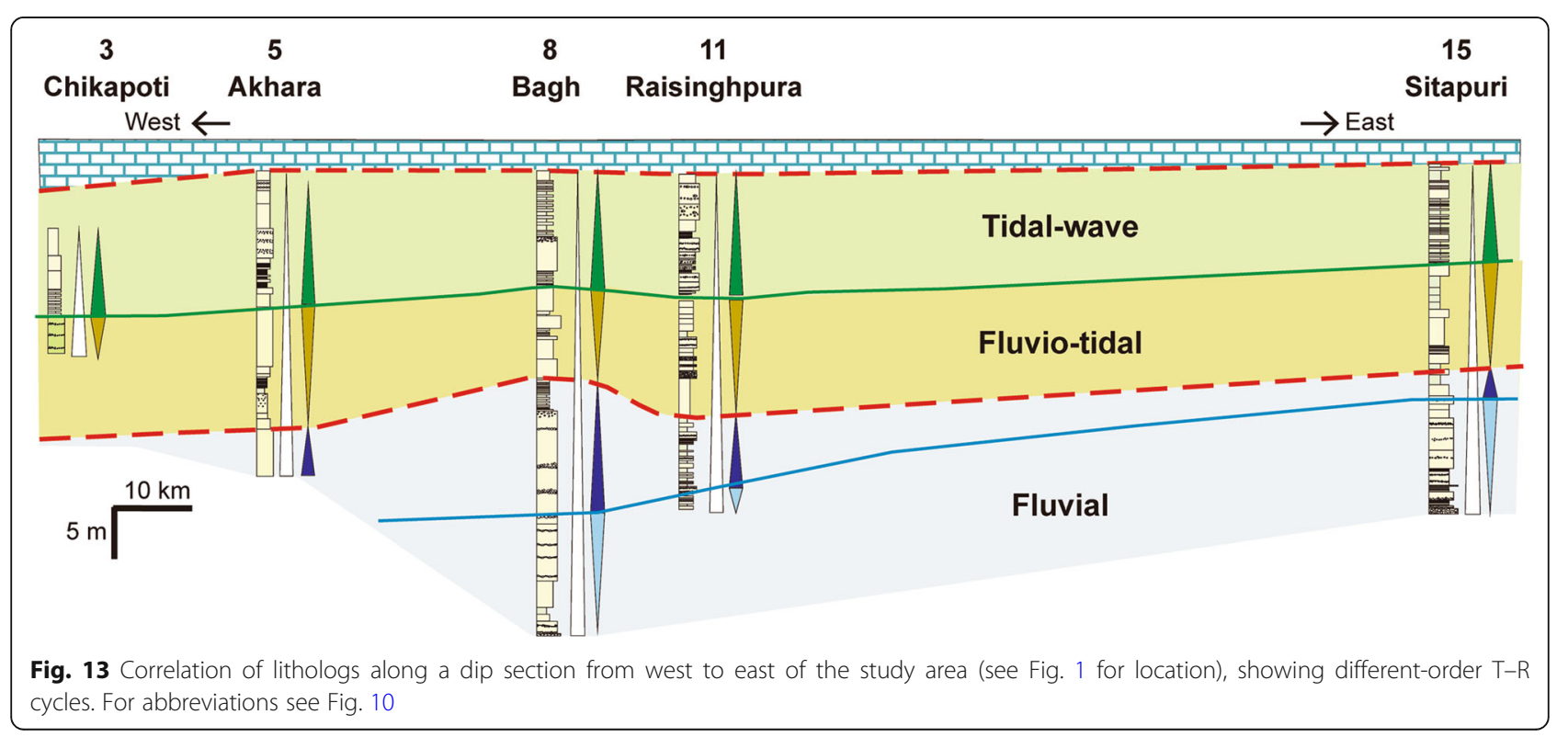




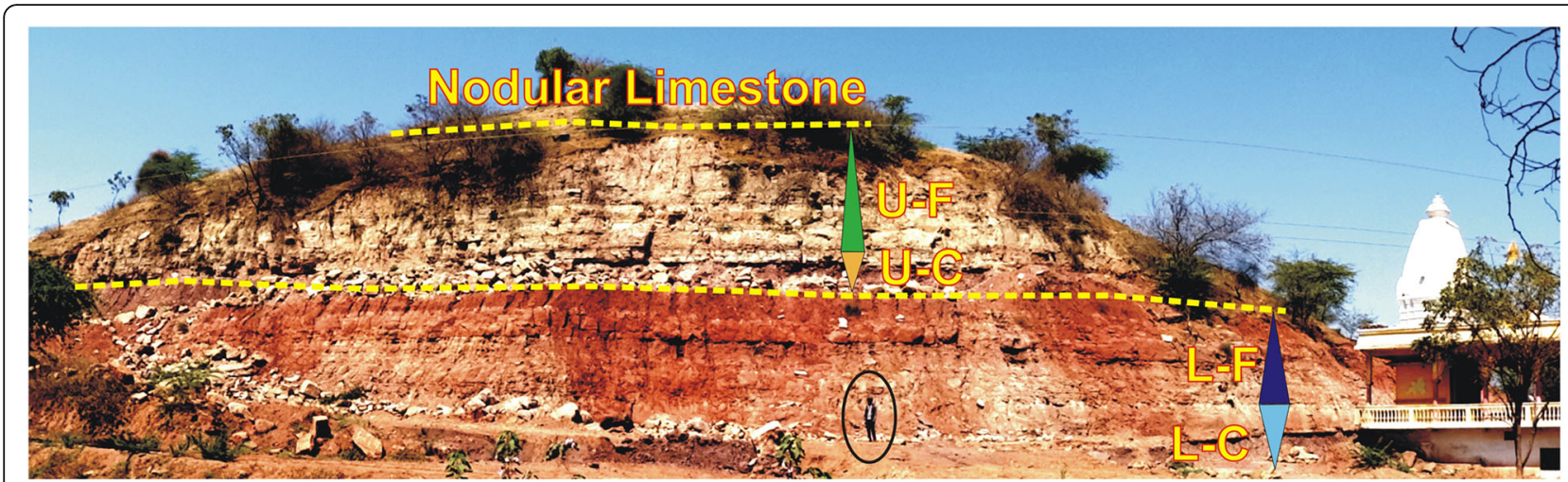

Fig. 14 A representative field section beside the Baghini Temple, near Bagh, showing four transgressive-regressive hemicycles (marked by L-C, LF, U-C and U-F). The person (encircled) is $172 \mathrm{~cm}$ tall. For key of abbreviations, see Fig. 10

basinal sagging in controlling the accommodation and sedimentation (Bhattacharya et al. 2016; Bhattacharya and Saha 2020).

The overlying coarsening-up hemicycle (U-C) in the middle to upper part of the succession, characterized by low to high tidal influence, shows a stacking pattern dominated by tide-reworked channel and overbank deposits (FA-3 and FA-4). Additional accommodation was available, as evident from high-accumulation of the tideaffected overbank deposits (FA-4) and low to high amalgamation of tide-influenced channels (FA-3). This net accommodation creation was controlled by a rising base level and landward encroaching sea, which was overpaced by a high rate of sedimentation led by both fluvial and tidal systems. The overall progradational stratal stacking pattern with less aggradation indicates a regressive condition, equivalent to a lowstand systems tract (LST) in the fluvio-marine transitional setting. In some areas (e.g., Bagh, Rampura, etc., Figs. 11, 13), particularly in places where the fluvial channels were strongly affected by tidal currents during this marine encroachment, tidally reworked coarser-grained clastics led to stacked, amalgamated thick channel-fill sandstone units (of FA-3). Such progradational stacking pattern confirms a lowstand condition, where a significant amount of sediment supplied by river was reworked by the encroaching tidal currents and was deposited as bayhead deltas and tidal bars in river mouth areas.

The lowstand stratal package is overlain by the topmost fining-up hemicycle (U-F) with a retrogradational

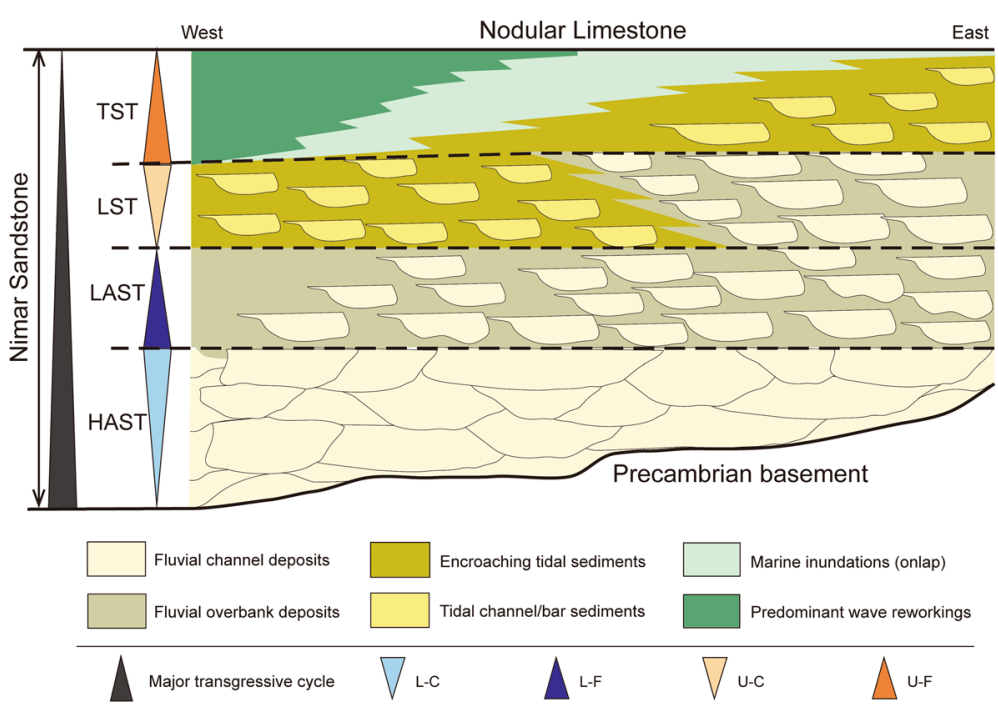

Fig. 15 Conceptual sequence stratigraphic model of the Nimar Sandstone Formation along a west-east transect through the study area, showing stratal stacking patterns with four high-frequency coarsening-up and fining-up hemicycles embedded in a major fining-up transgressive succession. Abbreviations see Fig. 10. HAST: High-amalgamation systems tract; LAST: Low-amalgamation systems tract; LST: Lowstand systems tract; TST: Transgressive systems tract 


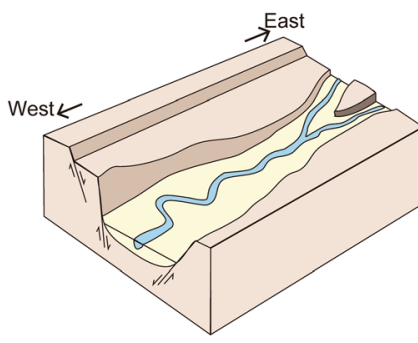

Stage 1: Initial phases of the sedimentation of Nimar Sandstone characterized by fluvial channel-fill and overbank deposits within a rift setting

Stage 2: Fluvio-marine interactions due to marine incursion led to development of an estuarine depositional system, with more marine influences towards the west

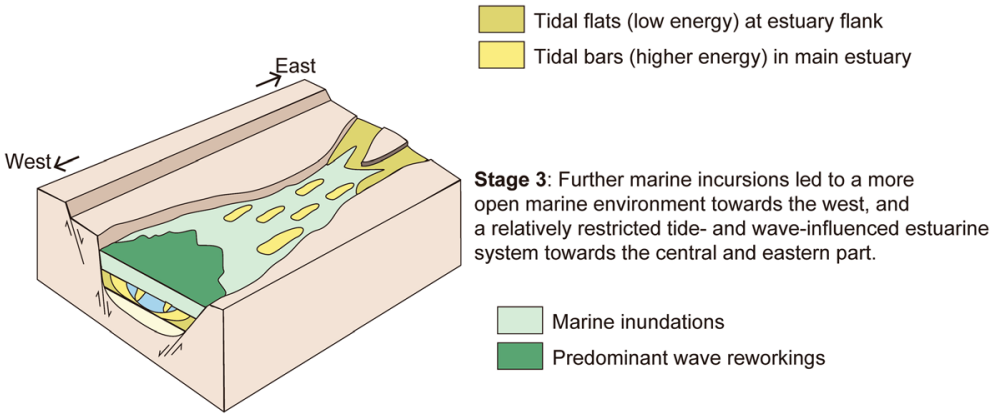

Precambrian basement

Fluvial deposits

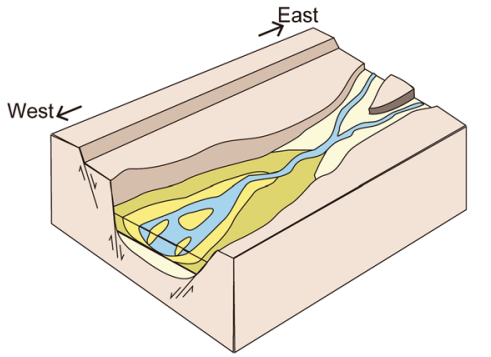

Tidal flats (low energy) at estuary flank

Tidal bars (higher energy) in main estuary

Marine inundation

wave reworkings

Fig. 16 Schematic 3D palaeogeographic model of the deposition of Nimar Sandstone Formation in the Narmada rift basin

stratal stacking pattern formed by predominantly tideand wave-produced sediments of FA-4 and FA-5 (Figs. 10, 11, 12 and 13). The prevalence of wave- and tide-controlled sedimentation with a low or rare signature of fluvial deposition suggests a coastal onlapping, which covered the earlier fluvial (HAST and LAST) and the fluvio-tidal (LST) deposits. A clear shift from pure fluvial depositional processes to open coastal depositional systems in different parts of the basin (Figs. 10, 11, 12 and 13) undoubtedly attests to a landward shift of the shoreline. Thus, the fining-up retrogradational stratal package in U-F represents a transgressive systems tract (TST). Minor variations in the stacking pattern within this TST in different areas are caused by varying water energy in different parts of the basin during the marine flooding event, which led to varied depositions from (i) wave-reworked shoreface sands with marine bivalves, gastropods, and trace fossils in the western part (more open marine), to (ii) finer-grained clastics with abundant Ostrea, Turritella and trace fossils (Thalassinoides) of marginal marine affinity, characteristic of brackish water conditions in the eastern part (landward, sheltered estuary-like). The contact with the overlying Nodular Limestone Formation (Fig. 14) is considered as the end of transgression documented by the Nimar Sandstone Formation succession; however, demarcating any definite surface (e.g., the maximum flooding surface) is not feasible due to the relatively poor preservation of features in outcrops and restricted lateral continuity of features.

\subsection{Sequence stratigraphic architecture}

In absence of absolute age data of the Nimar Sandstone Formation (as mentioned in Table 2), the chronological attributes of bounding surfaces and major events become problematic in the study area. The major transgressive cycle encompassing the entire Nimar Sandstone Formation succession definitely indicates a transgression. Since the lower contact of the Nimar Sandstone Formation is fault-bound, the actual starting age of the deposition is difficult to determine. The top boundary with the overlying Nodular Limestone Formation is conformable and indicates inland continuation of marine sedimentation. Thus, we may consider the major fining-up cycle in the Nimar Sandstone Formation as part of a major, continuous transgressive event. So, assigning the proper status of this major transgressive cycle in terms of sequence elements (sequence or systems tracts) is tricky and is avoided here.

The high-frequency $\mathrm{T}-\mathrm{R}$ cycles resemble different systems tracts, viz., L-C as HAST, L-F as LAST, U-C as LST, and U-F as TST, depending on characteristic stratal stacking patterns with assemblages of different facies 
associations (discussed earlier). Nature of the transition between the HAST and the LAST is gradual, rendering no definite bounding surface between them in field exposures. The changeover from the LAST and the overlying LST is commonly marked by initiation of tidal influence within the channel deposits and the progradation of these channel systems over the underlying overbank deposits. Sharp channel bases are locally identified in individual exposures, but poor preservation quality with lack of lateral continuity restricts the identification of a definite bounding surface between the LAST and the LST. Similarly, the changeover from LST to the topmost TST is not marked by any distinct surface such as the maximum regressive surface (MRS) and is mostly identified by the gradual change in the stratal stacking pattern from coarsening-up (U-C) to fining-up (U-F). The facies architecture near the upper boundary of the TST is not uniform throughout the sections and, in turn, makes it difficult to demarcate a definite terminating surface such as the maximum flooding surface (MFS). However, the Nodular Limestone Formation overlies this topmost TST throughout the study area, and definitely indicates the culmination of the transgressive event within the Nimar Sandstone Formation succession. Such variations in the facies architecture, causing difficulty in lateral correlation and identification of bounding surfaces of the sequence/systems tracts are due to the complex sedimentary facies distribution in the evolving fluvio-estuarine system within the riftogenic basin.

\subsection{Palaeogeography}

The Late Cretaceous global sea-level rise led to significant marine transgressions that affected part of western and central India (Acharya and Lahiri 1991; Singh and Mishra 2000; Desai 2013). This led to seawater inundation of large areas of central Indian land, resulting in a shift in depositional conditions from pure continental to marine/marginal marine. One such example of marine transgressions and change in depositional conditions is well recorded in the Upper Cretaceous Bagh Group, preserved within the Narmada rift basin.

Analysis of the Nimar Sandstone Formation succession in the light of transgressive-regressive cycles reveals a major transgressive event affecting the upper part of the succession. The initial fluvial system depicts an amalgamation of channel and overbank deposits under lowto-high accommodation conditions, mostly controlled by changing river equilibrium profile due to tectonic subsidence and varied sediment supply. This caused thick accumulation of channel-fill and overbank deposits in the lower part of the Nimar Sandstone Formation. An east-west flowing river system is reconstructed, with coarse sediments dominating in the east and fine sediments in the west. In the western part of the basin, the fluvial system was affected by tidal intermixing, indicating a significant marine encroachment and fluvio-tidal interference (Fig. 16). The effect of tidal influence is more pronounced in the upper transgressive hemicycle (U-C), which records prevalent drowning of the underlying fluvial system. The effect of this drowning was more dominant in the western part and less in the eastern part, indicating that the marine encroachment took place from west to east with the development of a tideinfluenced estuarine system in the west changing to more fluvial-dominated bay-head delta systems in the east. Overall facies architecture indicates that an initial fluvial depositional setting was engulfed by the development of a tide-influenced estuarine system (Fig. 16), where three distinct depositional zones can be deciphered, namely,

i) a fluvio-tidal interactive inner estuary zone, developed in the eastern part of the basin, characterized by the tide-reworked thick channel-fill and overbank deposits,

ii) a tide-dominated central estuary zone, developed in the central part of the basin, characterized by development of tidal sand bars and sand- and mud-flats based on the extent of inundations, mutual strength of tidal and fluvial systems, and type of net accommodation created, and.

iii) a tidal- and wave-dominated outer estuary part, developed in the western part of the basin, characterized by more open marine tide- and wave-reworked sediments of shore environments.

Successive stacking of high-frequency transgressiveregressive cycles was caused by fluctuations in the base level in response to the Cenomanian sea-level rise along with net sedimentation controlled by the basinal subsidence caused by reactivation of basin marginal faults in the Narmada rift basin (Jha et al. 2017). During the late stage of the transgression, outer estuarine open marine conditions encroached further landwards inundating the entire basin, which led to shallow, low-energy conditions with deposition of the Nodular Limestone Formation as an apron covering the underlying Nimar Sandstone Formation. Thus, the shift in depositional conditions from fluvialdominated to a transgressive tidal- to wave-influenced estuarine system attests to significant tectonosedimentary changes accompanied by prolonged events of marine transgressions in the Narmada rift basin during the Late Cretaceous.

\section{Conclusions}

The detailed facies analysis and sequence stratigraphic analysis of the Cenomanian Nimar Sandstone Formation helps to sort out the facies architecture in the fluviomarine interactive estuarine system. Based on the 
present study, we can frame the following conclusive remarks:

1) Detailed facies analysis records deposition of the lower part of the succession in a fluvial setting, which changed up-section into a transgressive fluvio-marine estuarine setting with: (i) a fluvialdominated inner estuary zone, with the transition from fluvial to tide-affected fluvial deposits, (ii) a transitional central estuary zone consisting of transitional fluvio-tidal channels and tidal flats, associated with tidal channels and bars, and (iii) a wavedominated shallow-marine outer estuary zone. This evolution is time-transgressive with a gradual shift of different depositional conditions in space and time.

2) Reactivation of basin-marginal faults during the Cenomanian time caused sequential subsidence of the land part within the Indian Plate, which enhanced the effective landward incursion of seawater due to the Cenomanian sea-level rise.

3) The major transgression is attributed to the Cenomanian global eustatic rise, whereas the highfrequency $\mathrm{T}-\mathrm{R}$ cycles indicate systematic variation in net sediment supply, change in accommodation space related to tectonic subsidence, and base level fluctuations, resulting in characteristic stratal stacking patterns.

4) The proposed tectono-sedimentary model based on the integrated sedimentological-sequence-stratigraphic study helps to reconstruct the palaeogeography in central India during the Late Cretaceous. Such a palaeogeographic model can be applied to similar transgressive fluvio-marine sedimentary successions formed in passive margin rift basins, where transgression is controlled by both eustatic changes and tectonic subsidence.

\section{Abbreviations}

HAST: High-amalgamation systems tract; IHS: Inclined heterolithic strata; LAST: Low-amalgamation systems tract; LST: Lowstand systems tract; MFS: Maximum flooding surface; MRS: Maximum regressive surface; SSDS: Soft-sediment deformation structures; T-R cycles: Transgressiveregressive cycles; TST: Transgressive systems tract

\section{Acknowledgements}

The authors like to thank IIT Roorkee for providing the research facilities. The authors gratefully acknowledge the thorough and critical reviews by two anonymous reviewers and the constructive comments of the editors of JoP.

\section{Authors' contributions}

$B B$ participated in the field work, identified and interpreted the primary sedimentary structures and the facies types, conceptualized the problem, completed the correlation of facies and facies associations in 2-D and 3-D, prepared the sequence stratigraphic models and drafted the manuscript. SJ has carried out the detailed descriptions of facies types, prepared the logs, participated in the field work and drafted the manuscript. PM has participated in the field, assisted in acquiring data and in lab analysis and drafted the manuscript. All the authors have read and approved the final manuscript.

\section{Funding}

Authors are thankful to the Ministry of Earth Sciences, Government of India, for financial support in the form of Extra-Mural Research Project (Ref. No. MoES/P.O.(Geo)/142/2017).

\section{Availability of data and materials}

The authors declare that the materials are available in open field area to be accessed by anyone. All data are collected by the authors themselves through fieldwork followed by laboratory analysis, and nothing has been supplied by any person or organization.

\section{Competing interests}

The authors declare that they have no competing interests. The authors alone are responsible for the content and writing of this article.

\section{Author details}

${ }^{1}$ Department of Earth Sciences, Indian Institute of Technology, Roorkee 247667, India. ${ }^{2}$ Geological Survey of India, Jabalpur 482003, India.

Received: 6 March 2020 Accepted: 16 October 2020

Published online: 25 November 2020

\section{References}

Acharya, S.K., and T.C. Lahiri. 1991. Cretaceous palaeogeography of Indian subcontinent: A review. Cretaceous Research 12: 3-12.

Badve, R.M., and M.A. Ghare. 1980. Ichnofauna of the Bagh beds from Deva river valley, south of Narmada. Biovigyanam 6: 121-130.

Banerjee, S., P. Ghosh, R. Nagendra, B. Bhattacharya, B.G. Desai, and A.K Srivastava. 2020. Marine and fluvial sedimentation including erosion and sediment flux in peninsular Indian Phanerozoic basins. Proceedings of the Indian National Science Academy 86 (1): 351-363.

Bansal, U., S. Banerjee, K. Pande, and D.K. Das. 2019. Unusual seawater composition of the late cretaceous Tethys imprinted in glauconite of Narmada basin, Central India. Geological Magazine 157 (2): 233-247.

Best, J.L., and R.A. Kostaschuk. 2002. An experimental study of turbulent flow over a low angle dune. Journal of Geophysical Research 107 (C9): 31-35.

Bhattacharya, B., S. Bandyopadhyay, S. Mahapatra, and S. Banerjee. 2012. Record of tide-wave influence on the coal-bearing Permian Barakar formation, Raniganj Basin, India. Sedimentary Geology 267-268: 25-35.

Bhattacharya, B., and P.P. Banerjee. 2015. Record of Permian Tethyan transgression in eastern India: A reappraisal of the barren measures formation, west Bokaro coalfield. Marine and Petroleum Geology 67: 170-179.

Bhattacharya, B., J. Bhattacharjee, S. Banerjee, S. Bandyopadhyay, and R. Das. 2016. Seismites in Permian Barakar formation, Raniganj Basin, India: Implications on lower Gondwana basin evolution. Arabian Journal of Geosciences 9 (4): 300. https://doi.org/10.1007/s12517-016-2318-9.

Bhattacharya, B., J. Bhattacharjee, S. Banerjee, S. Banerjee, and K. Adhikary. 2018. Early Permian transgressive-regressive cycles: Sequence stratigraphic reappraisal of the coal-bearing Barakar formation, Raniganj Basin, India. Journal of Earth System Science 127: 1-29.

Bhattacharya, B., and H.N. Bhattacharya. 2012. Implications of mud-clast conglomerates within late Paleozoic Talchir glaciomarine succession, Talchir Gondwana Basin, India. Indian Journal of Geosciences 66 (1): 69-78.

Bhattacharya, B., and S. Jha. 2014. Late cretaceous diurnal tidal system: A study from Nimar sandstone, Bagh group, Narmada Valley, Central India. Current Science 107 (6): 1032-1037.

Bhattacharya, B., and A. Saha. 2020. Large soft-sediment deformation structures (SSDS) in the Permian barren measures formation, PranhitaGodavari Valley, India: Potential link to syn-rift palaeoearthquake events. Journal of Palaeogeography 9 (1): 14. https://doi.org/10.1186/s42501-02000063-z.

Bhattacharya, H.N., and B. Bhattacharya. 2015. Lithofacies architecture and palaeogeography of the late Paleozoic glaciomarine Talchir formation, Raniganj Basin, India. Journal of Palaeogeography 4 (3): 269-283. 
Bhattacharya, H.N., B. Bhattacharya, A. Roy, and S. Pal. 2015. Late Archaean tidalites from western margin of Chitradurga greenstone belt, southern India. Precambrian Research 257: 109-113.

Boersma, J.R., and J.H.J. Terwindt. 1981. Neap-spring tide sequences of intertidal shoal deposits in a mesotidal estuary. Sedimentology 28 (2) 151-170.

Bose, P.K., and N.G. Das. 1986. A transgressive storm- and fair-weather wave dominated shelf sequence: Cretaceous Nimar formation, Chakrud, Madhya Pradesh, India. Sedimentary Geology 46 (1-2): 147-167.

Buatois, L., and M.G. Mángano. 2011. Ichnology: Organism-substrate interactions in space and time. Geology Magazine 149 (4): 750.

Catuneanu, O. 2017. Sequence stratigraphy: Guidelines for a standard methodology. In Stratigraphy and Timescales, vol. 2, 1-57. Elsevier, Oxford, UK.

Chiplonkar, G.W. 1974. Some unresolved aspects of the Bagh beds and Wadhwan formation (presidential address, seminar on Indian geology). Publication Center for Advance Study in Geology Chandigarh 11: 1A-10A.

Chiplonkar, G.W., and R.M. Badve. 1973. Age and affinities of the Bagh fauna - A reassessment. Bulletin of the Indian National Science Academy 45: $19-29$.

Chiplonkar, G.W., and M.A. Ghare. 1975. Some additional trace fossils from the Bagh beds. Bulletin of the Indian Geological Association 8 (1): 71-84.

Choi, K.S. 2010. Rhythmic climbing-ripple cross-lamination in inclined heterolithic stratification (IHS) of a macrotidal estuarine channel, Gomso Bay, west coast of Korea. Journal of Sedimentary Research 80 (6): 550-561.

Choi, K.S., R.W. Dalrymple, S.S. Chun, and S. Kim. 2004. Sedimentology of modern, inclined heterolithic stratification (IHS) in the macrotidal Han River delta, Korea. Journal of Sedimentary Research 74 (5): 677-689.

Dalrymple, R.W., and K.S. Choi. 2007. Morphologic and facies trends through the fluvial-marine transition in tide-dominated depositional systems: A schematic framework for environmental and sequence-stratigraphic interpretation. Earth-Science Reviews 81 (3-4): 135-174.

Dalrymple, R.W., B.A. Zaitlin, and R. Boyd. 1992. Estuarine facies models: Conceptual basis and stratigraphic implications. Journal of Sedimentary Petrology 62 (6): 1130-1146.

Desai, B.G. 2013. Ichnological analysis of transgressive marine tongue in prograding deltaic system: Evidences from Ukra Hill member, Western Kachchh, India. Journal of the Geological Society of India 82 (2): 143-152.

Eide, C.H., J.A. Howell, S.J. Buckley, A.W. Martinius, B.T. Oftedal, and G.A. Henstra. 2016. Facies model for a coarse-grained, tide-influenced delta: Gule horn formation (early Jurassic), Jameson land, Greenland. Sedimentology 63 (6): 1474-1506.

Elliott, T. 1986. Siliciclastic shorelines. In Sedimentary environments and Facies, ed. H.G. Reading, 155-188. Oxford: Blackwell Scientific Publications.

Förster, R., R. Meyer, and H. Risch. 1983. Ammoniten and planktonische Foraminiferen aus den Eibrunner Mergeln (Regensburger Kreide, Nordostbayern). Zitteliana 10: 123-141.

Gale, A.S., J. Hardenbol, B. Hathway, W.J. Kennedy, J.R. Young, and V. Phansalkar. 2002. Global correlation of Cenomanian (upper cretaceous) sequences: Evidence for Milankovitch control on sea level. Geology 30 (4): 291-294.

Ganguly, T., and S. Bardhan. 1993. Dimorphism in Placenticeras mintoi from the upper cretaceous Bagh beds, Central India. Cretaceous Research 14 (6): 747-756

Greb, S.F., and R.L. Martino. 2005. Fluvial-estuarine transitions in fluvialdominated succession: Examples from the lower Pennsylvanian of the central Appalachian Basin. Special Publication of the International Association of Sedimentologists 35: 425-451.

Gugliotta, M., Y. Saito, V.L. Nguyen, T.K.O. Ta, and T. Tamura. 2019. Sediment distribution and depositional processes along the fluvial to marine transition zone of the Mekong River delta, Vietnam. Sedimentology 66 (1): 146-164

Hallam, A. 1992. Phanerozoic Sea-level changes. New York: Columbia University Press.

Hancock, J.M., and E.G. Kauffman. 1979. The great transgressions of the late cretaceous. Journal of the Geological Society 136 (2): 175-186.
Haq, B.U. 2014. Cretaceous eustasy revisited. Global and Planetary Change 113: 44-58.

Haq, B.U., J. Hardenbol, and P.R. Vail. 1987. Chronology of fluctuating sea levels since the Triassic. Science 235: 1156-1167.

Harms, J.C., J.B. Southard, D.R. Spearing, and R.G. Walker. 1975. Depositional environments as interpreted from primary sedimentary structures and stratification sequences: Tulsa, Oklahoma. Society of Economic Paleontologists and Mineralogists (SEPM) Short Course 2: 161.

Harms, J.C., J.B. Southard, and R.G. Walker. 1982. Structures and Sequences in Clastic Rocks. SEPM Short Course No. 9. S.E.P.M., Tulsa, Okla., 851 pp.

Hilbrecht, H., M.A. Arthur, and S.O. Schlanger. 1986. The Cenomanian Turonian boundary event: Sedimentary, faunal and geochemical criteria developed from stratigraphic studies in NW-Germany. In: Global BioEvents, ed. O. Walliser. Lecture Notes in Earth Sciences 8: 345-351.

Jafar, S.A. 1982. Nannoplankton evidence of Turonian transgression along Narmada Valley, India, and Turonian-Coniacian boundary problem. Journal of the Palaeontological Society of India 27: 17-30.

Jaiswal, S., B. Bhattacharya, and S. Chakrabarty. 2018. High resolution sequence stratigraphy of middle Eocene Hazad member, Jambusarbroach block, Cambay Basin, India. Marine and Petroleum Geology 93: 79-94.

Jaitly, A.K., and R. Ajane. 2013. Comments on Placenticeras mintoi (Vredenburg, 1906) from the Bagh beds (late cretaceous), Central India with special reference to Turonian nodular limestone horizon. Journal of the Geological Society of India 81 (4): 565-574.

Jha, S., B. Bhattacharya, and S. Nandwani. 2017. Significance of seismites in the late cretaceous transgressive Nimar sandstone succession, sonNarmada rift valley, Central India. Geological Journal 52 (5): 768-783.

Khosla, A., V.V. Kapur, P.C. Sereno, J.A. Wilson, G.P. Wilson, D. Dutheil, A. Sahni, M.P. Singh, S. Kumar, and R.S. Rana. 2003. First dinosaur remains from the Cenomanian-Turonian Nimar sandstone (Bagh beds), district Dhar, Madhya Pradesh, India. Journal of the Palaeontological Society of India 48: 115-127.

Khosla, A., and A. Sahni. 2000. Late cretaceous (Maastrichtian) ostracodes from the Lameta formation, Jabalpur cantonment area, Madhya Pradesh, India. Journal of the Palaeontological Society of India 45: 57-78.

Klein, G.D. 1971. A sedimentary model for determining paleotidal range. GSA Bulletin 82: 2585-2592.

Kumar, P. 1994. Palynology of carbonaceous clays of the Nimar formation, Jhabua district, Madhya Pradesh, India. Journal of the Geological Society of India 44: 671-674.

Kundal, P., and B.N. Sanganwar. 1998. Stratigraphical, palaeogeographical and palaeoenvironmental significance of fossil calcareous algae from Nimar sandstone formation, Bagh group (Cenomanian-Turonian) of Pipaldehla, Jhabua Dt, MP. Current Science 75: 702-708.

Leopold, L.B., and M.G. Wolman. 1957. River Channel Patterns, Braided, Meandering and Straight, 282-B. U.S. Geological Survey Professional Paper, Washington D.C.

Malarkodi, N., S.J. Patel, P.J. Fayazudeen, and U.B. Mallikarjuna. 2009. Palaeoenvironmental significance of trace fossils from the Palaeocene sediments of the Pondicherry area, South India. Journal of the Geological Society of India 74 (6): 738-748.

Malaza, N., K. Liu, and B. Zhao. 2013. Facies analysis and depositional environments of the late Palaeozoic coal-bearing Madzaringwe formation in the Tshipise-Pafuri Basin, South Africa. ISRN Geology 11. https://doi.org/10.1155/2013/120380.

McGowen, J.H., and L.E. Garner. 1970. Physiographic features and stratification types of coarse-grained point bars: Modern and ancient examples. Sedimentology 14 (1-2): 77-111.

Miall, A.D. 1977. Lithofacies types and vertical profile models in braided river deposits: A summary. In Fluvial sedimentology, ed. A.D. Miall, 597-604. Calgary: Geological Survey of Canada.

Miall, A.D. 1982. Tertiary sedimentation and tectonics in the Judge Daly basin, Northeast Ellesmere Island Arctic Canada. Geological Survey of Canada Paper 80: 17-30.

Miall, A.D. 2006. The geology of fluvial deposits: Sedimentary Facies, analysis and petroleum geology. New York: Spring-Verlag. 
Miller, K.G., M.A. Kominz, J.V. Browning, J.D. Wright, G.S. Mountain, M.E. Katz, P.J. Sugarman, B.S. Cramer, N. Christie-Blick, and S.F. Pekar. 2005. The Phanerozoic record of global sea-level change. Science 310: 1293-1298.

Murty, K.N., B.G. Dhokarikar, and G.P. Verma. 1963. Plant fossils in Nimar sandstone near Umrali, M.P. Current Science 32 (1): 21-22.

Nagendra, R., B.V. Kamalak Kannan, G. Sen, H. Gilbert, D. Bakkiaraj, A. Nallapa Reddy, and B.C. Jaiprakash. 2011. Sequence surfaces and paleobathymetric trends in Albian to Maastrichtian sediments of Ariyalur area, Cauvery Basin, India. Marine and Petroleum Geology 28 (4): 895-905.

Nagendra, R., P. Sathiyamoorthy, S. Pattanayak, A. Nallapa Reddy, and B.C. Jaiprakash. 2013. Stratigraphy and paleobathymetric interpretation of the cretaceous Karai shale formation of Uttatur group, Tamil Nadu India. Stratigraphy and Geological Correlation 21 (7): 675-688.

Nichols, G. 2009. Sedimentology and stratigraphy. London: Blackwell Science Ltd.

Paola, C., S.M. Wiele, and M.A. Reinhart. 1989. Upper-regime parallel lamination as the result of turbulent sediment transport and lowamplitude bed forms. Sedimentology 36 (1): 47-59.

Raiverman, V. 1975. Facies transition among Nimar, Bagh and Lameta beds. Recent Researches in Geology 2: 123-139.

Reineck, H.E., and I.B. Singh. 1980. Depositional Sedimentary Environments: With Reference to Terrigenous Clastics, 549. Berlin: Springer-Verlag 2nd Rev. and updated ed.

Reineck, H.E., and F. Wunderlich. 1967. A new method to measure rate of deposition of single lamina on tidal flats and shelf bottoms. In 7th International Sedimentological Congress.

Reineck, H.E., and F. Wunderlich. 1969. Die Entstehung von Schichten und Schichtbänken im watt. Senckenbergiana Maritima 1: 85-106.

Richards, B.H., and J.P. Bhattacharya. 2018. Stratigraphy of the fluvial-tomarine transition zone associated with a forced-regressive compound incised-valley system in the Turonian Ferron Notom Delta, Utah, U.S.a. Journal of Sedimentary Research 88 (3): 311-326.

Röper, M., and M. Rothgaenger. 1995. Neue Fossilfunde aus der Regensburger Oberkreide. Teil 1: Eibrunner Mergel. Fossilien 3: 180-184.

Ruidas, D.K., S. Paul, and T.K. Gangopadhyay. 2018. A reappraisal of stratigraphy of Bagh group of rocks in Dhar District, Madhya Pradesh with an outline of origin of nodularity of nodular limestone formation. Journal of the Geological Society of India 92 (1): 19-26.

Sames, B., M. Wagreich, J.E. Wendler, B.U. Haq, C.P. Conrad, M.C. MelinteDobrinescu, X. Hu, I. Wendler, E. Wolfgring, I. Yilmaz, and S.O. Zorina. 2016. Review: Short-term sea-level changes in a greenhouse world - A view from the cretaceous. Palaeogeography Palaeoclimatology Palaeoecology 441 (Part 3): 393-411.

Sanganwar, B.N., and P. Kundal. 1997. Ichnofossils from Nimar sandstone formation, Bagh Group of Barwah area, Khargone district, Madhya Pradesh. Gondwana Geological Magazine 12 (1): 47-54.

Singh, D., and U.K. Mishra. 2000. Reconstruction of cretaceous basins of Meghalaya, India. Journal of Indian Association of Sedimentologists 19 (1): 59-68.

Singh, S.K., and H.K. Srivastava. 1981. Lithostratigraphy of Bagh beds and its correlation with Lameta beds. Journal of the Palaeontological Society of India 26: 77-85.

Skelton, P. 2003. The cretaceous world. Cambridge: Cambridge University Press.

Smith, A.B. 2010. The cretaceous Bagh formation, India: A Gondwanan window onto Turonian shallow-water echinoid faunas. Cretaceous Research 31 (4): 368-386.

Sundaram, R., R.A. Henderson, K. Ayyasami, and J.D. Stilwell. 2001. A lithostratigraphic revision and palaeoenvironmental assessment of the cretaceous system exposed in the onshore Cauvery Basin, southern India. Cretaceous Research 22 (6): 743-762.

Taylor, P.D., and R.M. Badve. 1995. A new cheilostome bryozoan from the cretaceous of India and Europe: A cyclostome homeomorph. Palaeontology 38 (3): 627-657.

Vail, P.R., F. Audemard, S.A. Bowman, P.N. Eisner, and C. Perez-Cruz. 1991. The stratigraphic signatures of tectonics, eustasy and sedimentology -
An overview. In Cycles and Events in Stratigraphy, ed. G. Einsele, W. Ricken, and A. Seilacher, 617-659. Berlin: Springer-Verlag.

van den Berg, J.H., J.R. Boersma, and A. van Gelder. 2007. Diagnostic sedimentary structures of the fluvial-tidal transition zone - Evidence from deposits of the Rhine and Meuse. Netherlands Journal of Geosciences - Geologie en Mijnbouw 86 (3): 287-306.

\section{Publisher's Note}

Springer Nature remains neutral with regard to jurisdictional claims in published maps and institutional affiliations.

\section{Submit your manuscript to a SpringerOpen ${ }^{\circ}$ journal and benefit from:}

- Convenient online submission

- Rigorous peer review

- Open access: articles freely available online

- High visibility within the field

- Retaining the copyright to your article

Submit your next manuscript at $\boldsymbol{\nabla}$ springeropen.com 